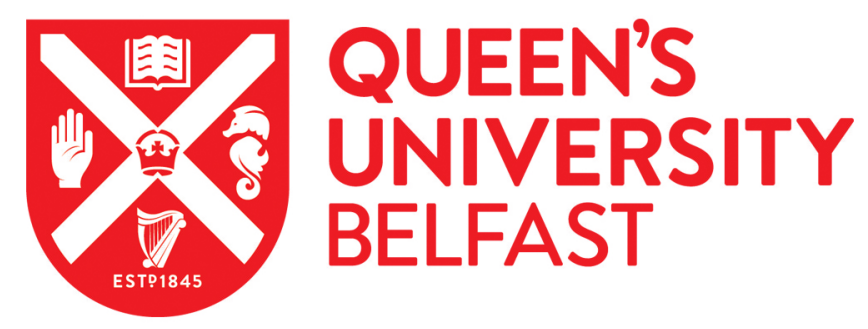

\title{
Radiocarbon chronology of occupation of the site Chicha and Bayesian statistics for the assessment of a discontinuous transition from Late Bronze to Early Iron Age (West Siberia)
}

Schneeweiss, J., Becker, F., Molodin, V. I., Parzinger, H., Marchenko, Z. V., \& Svyatko, S. V. (2018).

Radiocarbon chronology of occupation of the site Chicha and Bayesian statistics for the assessment of a discontinuous transition from Late Bronze to Early Iron Age (West Siberia). Russian Geology and Geophysics, 59(6), 635-651. https://doi.org/10.1016/j.rgg.2018.05.004

\section{Published in:}

Russian Geology and Geophysics

\section{Document Version:}

Peer reviewed version

Queen's University Belfast - Research Portal:

Link to publication record in Queen's University Belfast Research Portal

\section{Publisher rights}

Copyright 2018 Elsevier.

This manuscript is distributed under a Creative Commons Attribution-NonCommercial-NoDerivs License

(https://creativecommons.org/licenses/by-nc-nd/4.0/), which permits distribution and reproduction for non-commercial purposes, provided the author and source are cited.

\section{General rights}

Copyright for the publications made accessible via the Queen's University Belfast Research Portal is retained by the author(s) and / or other copyright owners and it is a condition of accessing these publications that users recognise and abide by the legal requirements associated with these rights.

\section{Take down policy}

The Research Portal is Queen's institutional repository that provides access to Queen's research output. Every effort has been made to ensure that content in the Research Portal does not infringe any person's rights, or applicable UK laws. If you discover content in the

Research Portal that you believe breaches copyright or violates any law, please contact openaccess@qub.ac.uk. 


\title{
THE LATE BRONZE TO IRON AGE TRANSITION IN WESTERN SIBERIA - CONTINUITY OR INTERRUPTION? BAYESIAN STATISTICS AND RADIOCARBON DATING IN THE CHICHA SETTLEMENT
}

\author{
J Schneewei $^{1}$, F Becker ${ }^{2}$, VI Molodin ${ }^{3,4}$, H Parzinger $^{6}$, ZV Marchenko ${ }^{3,4,5}$, SV Svyatko ${ }^{7}$ \\ ${ }^{1}$ Institute for the History of Material Culture, Russian Academy of Sciences, Dvorcovaya nab. 18, St. Petersburg \\ 191186, Russia \\ ${ }^{2}$ Freie Universität Berlin, Department of Earth Sciences, Institute of Geographical Sciences, Physical \\ Geography, Malteserstr. 74-100, 12249 Berlin, Germany
}

${ }^{3}$ Altai State University, Ave. Lenin, 61, Barnaul, 656049, Russia

${ }^{4}$ Institute of Archaeology and Ethnography, Siberian Branch of the Russian Academy of Sciences, Ave. Lavrentiev 17, Novosibirsk 630090, Russia

${ }^{5}$ Novosibirsk State University, Ave. Pirogov 2, Novosibirsk 630090, Russia

${ }^{6}$ Stiftung Preußischer Kulturbesitz, The president, Von-der-Heydt-Str. 16-18, 10785 Berlin, Germany

${ }^{7} 14$ CHRONO Centre for Climate, the Environment and Chronology, Queen's University Belfast, Northern Ireland, $U K$

\begin{abstract}
The Late Bronze to the Iron Age transition in Western Siberia involved significant cultural and political changes, which were reflected in the emergence of protourban settlements in the forest steppe zone. The transition is roughly dated to the turn from the $2^{\text {nd }}$ to the $1^{\text {st }}$ mil. $\mathrm{BC}$, mainly based on archaeological artefacts and on in general socio-cultural development. A more precise radiocarbon dating for this transition was problematic mainly because of a general lack of data in Western Siberia. This article analyses the chronology of the Late Bronze to Iron Age transition at Chicha, a reference site for this period in this region. The assessment of a possible hiatus between the Late Bronze Age and the following transitional period at Chicha is the key issue of our paper as its presence may have far reaching cultural implications. To increase the precision of the radiocarbon chronology with focus on the possible hiatus, the samples from well-defined stratigraphic contexts were analysed using Bayesian modelling that incorporated the stratigraphic information. The performed chronological modelling supports existing archaeological hypothesis of a hiatus in the very end of the $2^{\text {nd }}$ mil. $\mathrm{BC}$, just before a regular settlement of a new protourban settlement type appeared on the by then abandoned site. A sensitivity analysis including simulated hiatus confirms the reliability of the model. A complete population change seems to be plausible. The protourban settlement of Chicha, a typical feature for the Transitional period, didn't exist very long. With the emergence of the early nomadic cultures in the Southern Siberian steppes in the beginning of the $1^{\text {st }}$ mil BC it most probably stopped functioning. The cultural development of that time, former believed to be continuous, was deeply interrupted for several times.
\end{abstract}

\section{INTRODUCTION}

\subsection{Historical-cultural settings}

At the turn from the $2^{\text {nd }}$ to the $1^{\text {st }}$ mil. $\mathrm{BC}$, during the period of transition from the Bronze to the Iron Age in Western Siberia, significant cultural changes affected almost all aspects of society (e.g., Molodin 2010; Schneeweiß, Rjabogina 2014). This period also coincided with the time of climatic shifts to more humid conditions which resulted in the spread of forests southwards and expansion of the habitat for hunters and fishermen. These events terminated a relatively continuous development of the Bronze Age cultures in the forest-steppe and steppe zone. At the start of the new epoch (beginning of the $1^{\text {st }}$ mil. $\mathrm{BC}$ ), in the south, mobile nomadic tribes relatively quickly spread to the Asian steppe 
zones suitable for grazing. The earliest evidence for the arrival of nomadic horsemen $-9^{\text {th }} / 8^{\text {th }} \mathrm{c}$. BC has been found in monumental burial complexes in Tuva (Southern Siberia) (Parzinger 2004, 29-32; Parzinger 2006, 679).

The new cultural phenomenon of nomadic horsemen did not affect all regions of the steppe and forest steppe equally. In Western Siberia, this period (beginning of the $1^{\text {st }}$ mil. BC) is referred to as "Transitional" (Molodin 1979, 1985, Potemkina 1985, Troitskaya 1985, Kosarev 1987, Borzunov 1992, Chlenova 1994). A new type of settlements (large, fortified with regular buildings), previously unknown in the Western Siberian forest steppe, became a characteristic feature. Most likely, the innovations were influenced by the southern steppe population (Parzinger 2006, Molodin 2008, Pilipenko et al. 2008). At the moment, many issues of the cultural development in the Western Siberian forest-steppe zone in the end of the Transitional period and beginning of the Early Iron Age remain unresolved.

Determining of the exact chronology of the Bronze to Early Iron Age transition in Western Siberia is tightly related to the dating of the emergence of the first protourban settlements in the forest steppe. The settlements likely appeared in the beginning of the $1^{\text {st }}$ mil. BC in the same sudden way as monumental nomadic burial complexes in Southern Siberia. A fairly large radiocarbon database has been developed for the archaeological cultures of the Minusinsk Basin (Southern Siberia) (Görsdorf et al. 2001, Svyatko et al. 2009). It became essential for our understanding of the absolute chronology of the Bronze and Iron Age cultural development in Southern and Southwestern Siberia. The analysis of the chronological relationship between the appearance of nomadic societies in the Southern steppe and the protourban settlements in the forest-steppe is a conditio sine qua non for the understanding of their nature.

Chicha in the South of the Western Siberian Lowland is the reference site for protourban settlements in Western Siberia. The absolute chronology of this site is particularly important for dating of the Transitional period in Western Siberia. It is the best explored site of this period between Southern Siberia and the Trans-Urals. A series of radiocarbon dates has been obtained from stratified complexes of the site. These are the first absolute-chronological data for a set of LBA/EIA archaeological cultures of Western Siberia. The ${ }^{14} \mathrm{C}$ data from Chicha are particularly important to fill a gap between Southern Siberia and the East Trans-Urals, where the next series of radiocarbon data for this period come from (Görsdorf et al. 1998, Schneeweiß 2007, Molodin et al. 2012, Zakh et al. 2011, Zakh 2012, Multidisciplinary ... 2013, Molodin et al. 2014].

\subsection{Chronological modelling and Bayesian statistics}

Bayesian sequencing is a well-established approach in archaeology to combine absolute chronological information from scientific dating methods (such as ${ }^{14} \mathrm{C}$ dating) and archaeological information, e.g. a stratigraphical sequence of dates.

In short, unlike classical statistics, Bayesian statistics allow incorporating archaeological information i.e. "priors" - into chronological models. The priors are likelihoods which describe the relationship between two (or more) dates. In terms of radiocarbon dating, the modelled probability function of a date (the posterior probability distribution) is a function of the calibrated ${ }^{14} \mathrm{C}$ dates (the prior likelihood) and the archaeological prior information (for an introduction see e.g. Bayliss 2009; for details on mathematical solutions see e.g. Buck et al. 1996, Bronk Ramsey 2009 or Weninger 2011).

In archaeology, application of Bayesian chronological modelling is common since the early 1990s (Buck et al. 1992, 1996, van der Plicht 1993, Bronk Ramsey 1994, 1995, Christen 1994, Christen et al. 1995), specifically for re-assessing established chronologies (e.g. Bronk Ramsey et al. 2004, Friedrich et al. 2006, Höflmayer 2012, Friedrich et al. 2014, and Wiener 2014 for the Santorini case). For studying settlement history, Bayesian approaches were used to successfully find one or more hiatus 
between archaeological phases (e.g. Bachand 2008, Hamilton 2010, Dye 2011, Riede and Edinborough 2012, Wardle et al. 2014). Thus, Bayesian chronological modelling appears to be useful for analysis of the proposed hiatus in Chicha (see below). Nevertheless, the above mentioned studies lack a critical assessment of the model assumptions - both archaeological and methodological - as claimed by i.a. Steier et al. 2001, Bayliss et al. 2007, or Weninger et al. 2010. For the chronology of Chicha settlement we undertook a critical assessment of all model steps.

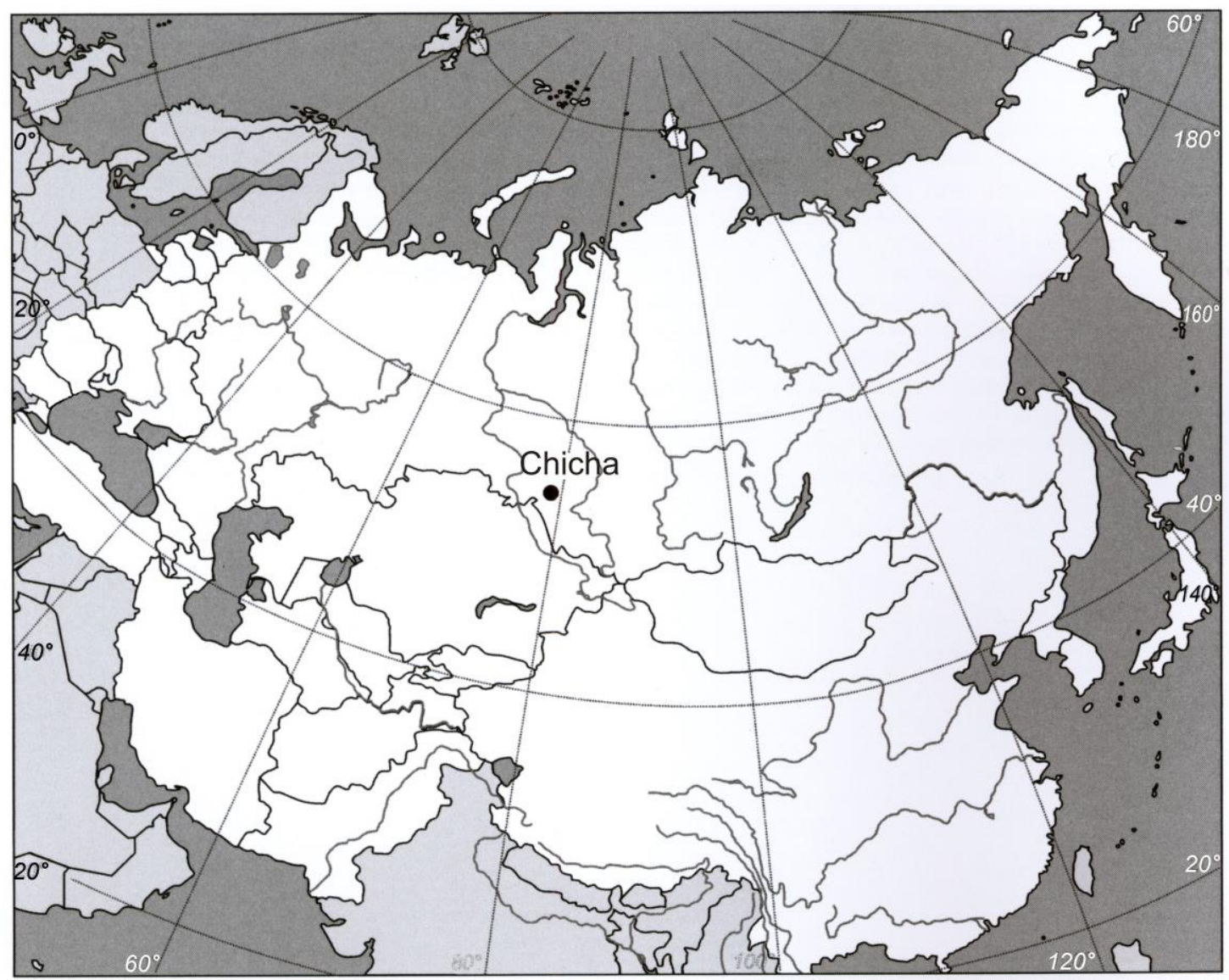

Figure 1: The position of the Chicha site in central Northern Eurasia (Western Siberia).

\subsection{Chicha site description}

The Chicha site is located in the south of the Baraba forest-steppe on the shore of the Small Chicha Lake (54 43'11"N 78 35'27"E; Figure 1 and 2). First excavations in Chicha were performed in 1979 (Molodin 1985, Molodin et al. 1999). In 1999-2003, a large-scale interdisciplinary Russian-German research project took place (Molodin et al. 2001a, 2001b, 2002a, 2002b, 2004, Schneeweiß 2007, Molodin and Parzinger 2009). A total area of $3500 \mathrm{~m}^{2}$ was uncovered, including 21 dwellings (mainly half-sunken pit houses), fortification structures (moats) and several burials. The preceding geomagnetic survey revealed a five hectare plan of a fortified settlement with a clear layout of buildings, and a necropolis beside it (Becker H and Fassbinder 1999, Molodin et al. 1999). Referring to this magnetometer plan, the settlement was conventionally divided by archaeologists into a "Citadel" (the only preserved, unploughed part of the site at the edge of the lake terrace; Figure 2) and a "Periphery" or "outer settlement" (the major ploughed area of the site with a regular plan). The new radiocarbon dates, as well as comparative-typological analysis of bronze objects, generally attributed the Late Bronze Age - Transitional period settlement at Chicha to the $14^{\text {th }}-9^{\text {th }} / 8^{\text {th }} \mathrm{c}$. BC (Schneeweiß 2007, Molodin 2008, Molodin and Parzinger 2009). 


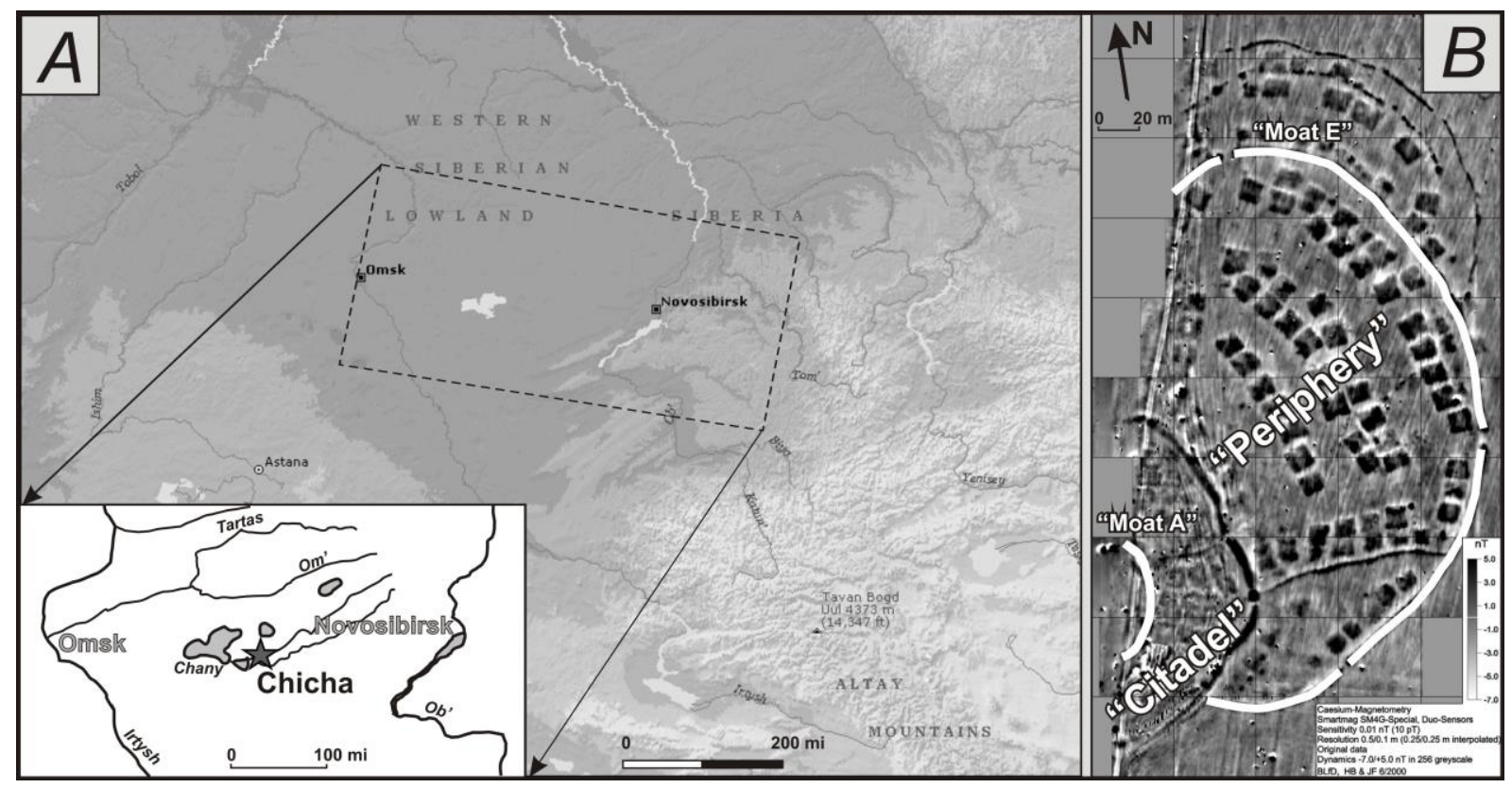

Figure 2: Chicha site in the Western Siberian Lowlands between the $\mathrm{Ob}^{\prime}$ and Irtysh rivers (A) and the magnetometer plan of the settlement part of the site with division into "Citadel" and "Periphery" parts (B).

Analysis of planigraphy, stratigraphy, artefacts (first of all pottery and bronze objects) and scientific data revealed the relative chronology of the site and the key stages of its development (Molodin et al. 2003, Schneeweiß 2007, Molodin and Parzinger 2009). However, there are several approaches regarding the settlement phases. Based on the dynamics of the supposed spatial development of the site, some scholars propose four main construction phases with six sub-phases for the Late Bronze Age and the Transitional period (Molodin et al. 2003). Among these, phases 1 and 2 refer to the Late Bronze Age population of the "Citadel" area by the Irmen culture people, while the construction phases 3 and 4 refer to the arrival of a migrant population in the Transitional period with different pottery in the "Periphery" area. Another approach, mainly relying on the chronostratigraphical and typological analyses of pottery (Schneeweiß 2007), is tending to distinguish three main successive phases: the Late Bronze Age period as phase 1, the Transitional period from Bronze to the Early Iron Age as phase 2, and the later Early Iron Age as phase $3^{1}$. According to this approach, the phase 2 settlement extended over the entire territory of the site, while the phase 1 and 3 settlements were more or less restricted to the "Citadel" area at the immediate lake shore. However, the Late Bronze Age necropolis (phase 1) was located outside the "Citadel" area and partly overlapped with the "peripheral" phase 2 settlement (Schneeweiß 2007). This was confirmed by a detailed typological analysis of small finds (Molodin and Parzinger 2009).

Thus, in essence, the different approaches outline the similar periodisation of the site, with two main controversial points, namely - the exact moment and character of the transition from the first stage (Late Bronze Age) to the second stage (Transitional period from Bronze to Iron Age), and the nature of the Late Irmen culture as either an independent culture of the Transitional period (Molodin and Parzinger 2009) or as an advanced stage of the Late Bronze Age Irmen culture (Molodin 1985, Schneeweiß 2007). The Irmen culture is a well studied archaeological culture of the Late Bronze Age in the Western Siberian forest zone between the Irtysh and Ob river valleys (Molodin 1985, Matveev 1993). It is synchronous and related to the well-known Karasuk culture of the Minusinsk Basin. In this paper we argue the chronological relationship between the first two main stages of the site, with the

\footnotetext{
${ }^{1}$ The cultural layers of the succeeding Early Iron Age (phase 3 by Schneeweiß 2007) are beyond the focus of this paper, so are not considered here.
} 
cultural implications to be discussed elsewhere. We are focusing, firstly, on the nature of the transition from the first to the second settlement phase, and, secondly, on its exact dating. We consider a probable hiatus between those two phases as a key issue. Closely related to this topic is the dating of the protourban-like "Periphery" of the settlement, which probably marks the beginning of the transitional period from Bronze to Iron Age in the Western Siberian forest-steppe zone.

\section{MATERIAL AND METHODS}

\subsection{Stratigraphical information}

Stratigraphical observations are of major importance for arguing the development of the Chicha site through time and space. It has been pointed out that pit houses or half-sunken pit houses of the foreststeppe zone cannot be considered as closed complexes, as the inventory of the filling was often accumulating over a long period, in some cases over hundreds of years (Gryaznov 1956, Matveev 1993, Schneeweiß 2007). The usually deep black colour of the cultural layers and the high portion of bioturbations make it nearly impossible to recognize different layers within the fillings. So in Chicha it was only possible to distinguish a certain floor level of a house by in situ finds of crushed vessels. The filling of the different moats provided, in contrast, quite recognizable layers, so that the analysis of the stratigraphy using Harris-Matrix revealed reliable results (Schneeweiß 2007). It also needs to be kept in mind that a significant proportion of the finds has been relocated by taphonomic processes.

The interpretation of stratigraphical information is not the only, but the main argument in favour of the existence of a chronological hiatus between the Late Bronze Age and the Transitional Period phases in Chicha. Further indirect evidence derives from the typological analysis of the pottery and the archaeozoological data (Schneeweiß 2007). The archaeological interpretation of the stratigraphic sequence, supported by Harris-Matrix, provided the initial point for modelling of the absolute chronology.

\subsection{Sampling and radiocarbon dating}

The most complex stratigraphy was observed in the cross-sections of the moats in the "Citadel" area. Fillings of moats were often cut through or overlaid by sunken dwellings or pits; multiple digging activities led to a significant redeposition of older material. This made the chronological analysis of layers and structures difficult. Thus, sampling was always accompanied by taphonomic observations and careful assessment of the specimen provenance. Despite we attempted to sample only the most reliable parts of stratigraphical contexts, the redeposition of earlier material could not be completely excluded. Apparently as a result of this, the radiocarbon data put into a stratigraphic order showed a number of inconsistencies (e.g., Hd-24527) (Schneeweiß 2007, Abb. 19). Therefore, before including the data in statistics and modelling, the individual assessment of each date concerning the compliance with the stratigraphy was carried out.

A series of 45 radiocarbon dates was obtained from different material (Appendix 1, cf. Schneeweiß 2007, Appendix 3): charcoal, bone samples of herbivores (elk, horse), man, fish, as well as residues on potsherds and soil samples (humic acid).

\subsection{Prior and model specifications}

We used OxCal v. 4.2 (Bronk Ramsey 2009) and the IntCal13 calibration curve (Reimer et al. 2013) for calibration and chronological modelling of the radiocarbon measurements from Chicha, already published by Schneeweiß 2007 (Appendix 3). All models were written in the Chronological Query Language of OxCal (Bronk Ramsey 1998).

For the estimation of dating and duration of the "hiatus" between the first two phases in the development of the Chicha site, 45 models were developed in OxCal. Each of them includes different 
variants of archaeological assumptions. The main chronological models are presented by Becker $\mathrm{F}$ and Schneeweiß (2016). In this study, six models are discussed in detail (0, I, II, IIIa, IIIb, IIIc).

The main prior information of all models is the stratigraphic sequencing elaborated by Schneeweiß (2007). Based on that, following up models were set up by an recursive adjustment of model assumptions (as described in Bayliss 2009). The main criterion not to reject a model and to revisit the prior information is the agreement index (Bronk Ramsey 1995) of single ages (A) and the model ( $\left.A_{\text {model }}\right)$. The agreement index indicates to what degree a modelled age matches the original data.

The unconditional null model (M0) is only based on stratigraphic sequencing, without explicitly modelling a Sequence in OxCal; a Sequence is implicitly modelled in Model I (MI).

All dates where $\mathrm{A}<60 \%$ were successively analysed and revisited in relation to the archaeological context of the dated sample, beginning with the date with the lowest agreement index. The appropriate prior information for each date were included in a new model (MII1, ..., MIIn). The stop criterion for the successive integration of new prior information is an agreement index of the model $A_{\text {model }}>60 \%$. A final Model including all prior information is shown in Figure 3. The priors include firstly a terminus post quem (TPQ, After) of an elk bone from a filling layer, which might have been redeposited; the samples of this layer are characterized by an age inversion, as the sample stratigraphically overlies a much younger one. The same is true for other samples, which were taken from a thick, mixed, ashy layer. Samples from this burnt layer "Prokal 6" and stratigraphically encircled dates ${ }^{2}$ were summarized in a second prior - Phase; thus, a sequence of these samples is not modelled. The genesis of this burnt layer may be explained by earthworks e.g. surface grading after a fire event. A third prior apply for Model II are Outlier, which are samples from moat E (trench 1), which were set as TQP beforehand or are insufficiently modelled $(\mathrm{A}<60 \%)$.

Ages from bulk organic soil samples were excluded from Model II, as they do not clearly date any process related to the settlement activity in Chicha, but rather soil formation processes. Fourthly and finally, multiple dates from the same sample were combined (Combine).

Based on Model II, the late Bronze Age period and the Transitional period are explicitly incorporated in the model (Model III, Figure 3; Sequence and Boundary). We used three different prior distributions - a uniform prior (Model IIIa) and two types of trapezoid prior (Models IIIb and IIIc) - to model the archaeological activity ( $s c$. deposition) in each of the phases. Whereas the uniform prior (e.g. Bronk Ramsey 2008) is based on the assumption of a uniform deposition of material in a specific phase - and thus a more or less abrupt end/start of the phase - the trapezoid prior (Boundary and Transition; Karlsberg 2006, Bronk Ramsey and Lee 2012) is divided into three sections; a transitional phase of increasing deposition of material, a main phase of constant deposition and a terminal phase of decreasing deposition. Our first trapezoid model (IIIb) assumes a transitional and a terminal phase for both archaeological phases, whereas the second trapezoid model assumes no terminal phase at the end of the late Bronze Age period assuming a devastating fire event (IIIc).

\section{Test for hiatus}

We used the Interval-query in $\mathrm{OxCal}$ as a statistical tool to test the significance of a possible hiatus between the late Bronze Age period and the Transitional period, accepting an interval as significant if the lower boundary of its confidence interval is $\geq 1$.

\footnotetext{
2 KIA-12434, Bln-5536, KIA-16426, BIn-5534, Bln-5535, Bln-5294, Bln-5614, Bln-5485A.
} 
End Boundary

Bln-5419 R_Date(2551,38) [A:156]

Bln-5418 R_Date $(2623,54)[$ A:165]

Bln-5298 R_Date $(2643,30)$ [A:125]

Bln-5482 R_Date $(2665,34)[$ A:138]

Bln-5297 R_Date $(2677,42)$ [A:130]

KIA-18874 R_Date $(2684,24)[A: 90]$

BIn-5477 R_Date(2736,27) [A:114]

Bln-5481 R_Date(2705,37) [A:93]

[ Hd-24518 R_Date(2929,31) [A:100]

soil organic material After

KIA-18871 R_Date 2793,28$)$ [A:102]

parallel layer Phase

BIn-5412 R_Date $(2813,27)$ [A:98]

KIA-12437 R_Date(2680,36)? [P:o]

KIA-16430 R_Date(2773,30) [A:103]

KIA-12435 R_Date 2812,28$)$ [A:120]

KIA-16428 R_Date $(2818,25)$ [A:116]

KIA-12436 R_Date(2824,36) [A:125]

Bln-5417 R_Date $(2838,32)$ [A:125]

KIA-16429 R_Date $(2839,27)$ [A:103]

KIA-12433 R_Date $(2878,26)$ [A:121]

Bln-5478 R_Date(2890,31) [A:124]

Bln-5479 R_Date(2891,34) [A:115]

[Bln-5486 R_Date $(3027,28)$ [A:100]

major earthworks After

KIA-12438 R_Date(3048,39)? [P:1]

KIA-18873 R_Date $(3128,28)$ [A:100]

moved bone After

Bln 5485A R_Date(2959,34) [A:107]

Bln-5614 R_Date(2959,32) [A:123]

Bln-5294 R_Date $(2933,28)$ [A:108]

Bln-5535 R_Date(2996,32) [A:118]

Bln-5534 R_Date(2999,34) [A:139]

Bln-5536 R_Date(3032,30) [A:120]

KIA-16426 R_Date $(3045,28)$ [A:115]

KIA-12434 R_Date(3045,38) [A:123]

Bln 5484A R_Date(3071,36) [A:113]

Bln-5533 R_Date(3082,32) [A:117]

KIA-16427 R_Date $(3086,27)$ [A:115]

Bln-5483 R_Date(3087,30) [A:106]

BIn-5532 R_Date(3018,33) [A:70]

KIA-12439A R_Date(3080,28) [A:107]

KIA-12439B R_Date(3106,26) [A:116]

Bln-5480 R_Date(3128,32) [A:132]

Begin Boundary

FB's model (1, dates) Sequence [Amodel:238]

3600

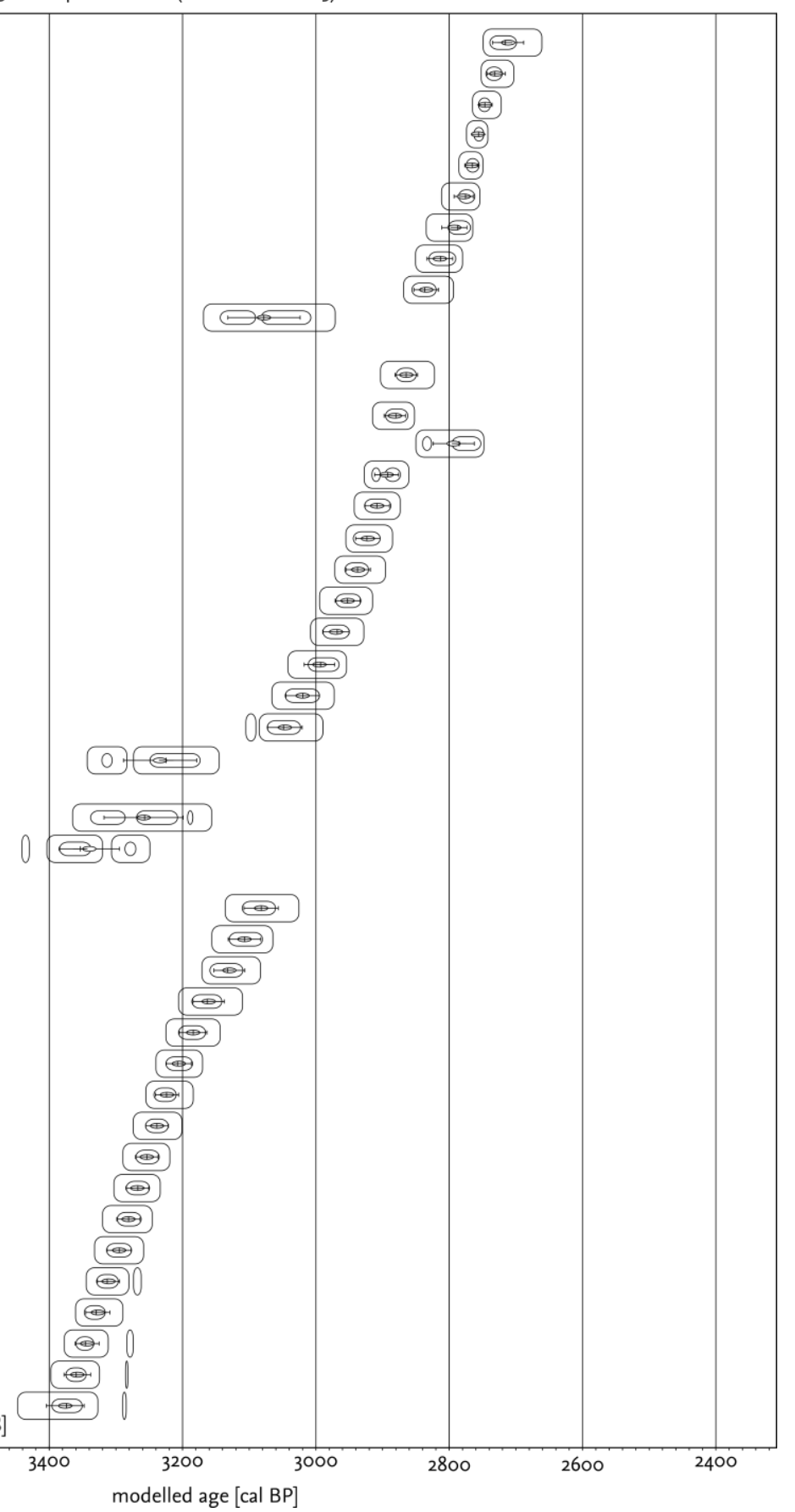

Figure 3: Stratigraphical model of all dates included in the chronological models: statistical measures (64.2\% and $95.4 \%$ levels of confidence, median, and standard deviation) of posteriori age distributions; Phases and periodization are not included in the model (see Figure 4). 


\section{Sensitivity analysis}

As models from a limited set of radiocarbon dates with archaeological prior information are lacking an independent age control (e.g. Telford et al. 2004), chronological models are per se wrong (ibid, Bayliss et al. 2007). In addition, single prior information (here, the separation of the sequence in two phases) can be a strong assumption (Scott 2000) and have a huge impact on the results of the chronological models. Nevertheless, there are several techniques to cope with uncertainty and strong assumptions in the models, such as leave-p-out cross-validation, or age simulations (Telford et al. 2004, Bayliss et al. 2007). As leave- $p$-out cross-validation might not be suitable for the Chicha-dataset (only a few - the marginal dates of the periods - are relevant for the problem under observation), we applied a critical sensitivity analysis (sensu Buck and Menson 2015) of all model parameters, including the uncalibrated ${ }^{14} \mathrm{C}$ measurements, the calibration curve, and the main archaeological prior information.

The sensitivity of the uncalibrated ${ }^{14} \mathrm{C}$ measurements was tested by multiplying the laboratory error of the measurements by a factor of $0.5,1.5$, and 2.0. In addition, the mean of the gauss distributed ${ }^{14} \mathrm{C}$ dates were changed by \pm 40 and \pm 80 years. To test the influence of the calibration curve uncertainty, we calibrated the radiocarbon measurements applying IntCal13 (Reimer et al. 2013), but also IntCal98 (Stuiver et al. 1998), IntCal04 (Reimer et al. 2004), and IntCal09 (Reimer et al. 2009).

As one of the main foci of the present paper is the possible chronological gap, we had to cope with the problem of an increase in the precision of the hiatus duration at the expense of its accuracy (e.g. Steier and Rom 2000), and thus having an importantly wrong model (sensu Bayliss et al. 2007). In addition, we run the risk to simply preconceive the archaeological chronological framework if we use the preexisting periodisation as prior information for the models (cf. Griffiths 2014).

Thus, we insert simulated hiatus in the model by setting the position of the end of a first hypothetical period (ergo Sequence) and the beginning of a second hypothetical period in the model. In consequence, the significance of the archaeologically sound hiatus is only valid if randomly simulated hiatus are not significant. Otherwise, the significance of a hiatus might only be an immanent characteristic of the chronological model but not inevitably of the archaeological data.

Also the use of different prior distributions (uniform/trapezoid) is part of the sensitivity analysis.

\section{RESULTS}

\subsection{The relative chronology}

The reconstruction of the relative chronology of the site development in Chicha is based mainly on stratigraphical observations and typological investigations. The same is true for the consideration of the existence of a hiatus in the development of the Chicha settlement. Detailed analysis of the stratigraphy of the site on the basis of representative cross sections has been previously presented from different perspectives (Schneeweiß 2007, Molodin et al. 2008b, Becker F and Schneeweiß 2016). The most complex stratigraphy was found in the central part of the site, the so-called "Citadel". Multiple reconstructions and re-use led to multilayered deposits in that area, while those alterations remained rare in the area of the so-called "Periphery". The oldest structures are represented by the moat A and several large pits on its bottom (Figure 2B).

The deposits at the bottom of the moat A mainly consisted of thin layers of domestic waste (mainly consisting of large amounts of animal bones and fish remains). The nature of deposits gives reason to assume that the moat remained open for a long time. The ceramics from the lowest layers of the moat filling belong exclusively to the Late Bronze Age. At a moment when moat A was already partially filled, the dwelling 21 and the construction 24 were cut into its filling. Those features also belong to 
the Late Bronze Age. The construction 24 obviously was burnt down. Further to the north, a thick layer of burned rubble was deposited in the moat A. Therefore, the end of the first settlement phase in Chicha in the Late Bronze Age is considered to be connected to a hostile fire (phase 1). Subsequently, the moat A was completely filled, and dwelling pits were made, partially cutting into its filling and borders $^{3}$. It is very likely that those reconstructions were connected to a modified general plan of the dwelling locations beyond the former moat A, including the "Citadel" as well as the "Periphery". In the dwelling pits of the "Citadel" area, several occupation layers have been detected, which cannot be stratigraphically connected to specific construction horizons ${ }^{4}$. The different occupation horizons could only be recognized by burnt layers and, specifically, crushed ceramic vessels (e.g. Schneeweiß 2007, 20-21, Abb. 13). The reconstruction of the exact settlement structure or the shape of the Late Bronze Age dwellings and that of the following periods in the "Citadel" remains impossible because of multiple significant earthworks in prehistoric times. Stratigraphical observations within the "Citadel" reveal evidence for a long-term development of Chicha. The settlement structure was changed several times. Every phase of the site development (Late Bronze Age, Transitional period and Early Iron Age) included several sub-phases, which left their particular characteristics. So it has to be recognized that, in general, the structure of the site is much more complex than it was thought before referring just to the magnetogram. Analysis of the Chicha pottery revealed also a remarkable cultural diversity, which can be interpreted in different ways (Schneeweiß 2007, Molodin et al. 2008a, 2009a; see below).

The "Periphery" shows a different picture. This area was ploughed for a long time, so that this part of the site was levelled and no features were visible above ground. However, this levelling resulted in a much clearer magnetogram than in the unploughed "Citadel" area. The dwelling pits most likely were not filled straight after their abandonment, but remained open for a long time. Very likely, they were completely filled only by subrecent ploughing. In the periphery, burials of the Late Bronze Age, synchronous to the earliest settlement in the "Citadel", were found (phase 1). During the Transitional period (phase 2), the built-up area included parts of the older necropolis, and it is obvious that the constructors were negligent of the burials. Thus, the surface indications for the burials were either levelled naturally, or the (new) population did not recognize the burials as their own and neglected or destroyed them. We do not know any burials belonging to the Transitional period (phase 2), except a number of infant ones inside the dwellings. The lack of burials is a general phenomenon of the Transitional period in the forest-steppe zone. Several cemeteries dating to the beginning of the $1^{\text {st }}$ mil. $\mathrm{BC}$ were investigated in adjacent southern regions, such as the Zevakinskij site in the East Kazakhstan Irtysh River basin (Arslanova 1974), Izmajlovskij (Ermolaeva 1974), as well as some other single complexes of that time (Ermolaeva 1985, Samashev and Bokovenko 1985), including Northern Kazakhstan sites (Khabdulina 1986).

\subsection{Modelling the absolute chronology - Posterior probabilities and the question of a hiatus}

The radiocarbon dates in our database calibrate to ranges between 1495-1296 cal BC (beginning of activity in the Late Bronze Age period) and 806-543 cal BC (end of Transitional period) at 95.4\% probability ("Model 0"). The last conventional date of Prokal 6 (the last dates in the Late Bronze Age period) and the earliest dates of the Transitional period intercept with a small plateau of the calibration curve, thus having relatively wide confidence intervals compared to other dates (for details see Becker $\mathrm{F}$ and Schneeweiß 2016). The end of the Late Bronze Age period calibrates to 1269-1051 cal BC (or 1224-1119 at $68.4 \%$ probability; latest date), whereas the beginning of the Transitional period calibrates to $1208-977$ cal BC (or 1224-1119 at $68.4 \%$ probability; first date). Based on (prior) likelihoods, a hiatus between the Late Bronze Age and the Transitional period is not evident, as the marginal dates of the periods clearly overlap.

\footnotetext{
${ }^{3}$ First of all the second phase of dwelling 21 and construction 23.

${ }^{4}$ Dwellings 3, 3a, 3b, 17, 20, 20a.
} 
The posterior 68.4 and $95.8 \%$ modelled age ranges are summarized in Table 1 . With a simple singlephase model (Model I) age ranges are slightly different from the calibrated ranges. Activity in the Late Bronze Age period is modelled to have ended 1188-1079 cal BC (youngest age) at $95.8 \%$ confidence, the beginning of the Transitional phase dates between 1157 and $1044 \mathrm{cal} \mathrm{BC}$. At $68.4 \%$ confidence, the end of the first period and the beginning of the second period date to the ranges of 1162-1112 and 1125-1075 cal BC, respectively. Thus, the marginal dates of the two periods are overlapping at both levels of confidence; the model yield a $95.8 \%$ duration of the hiatus of $0-86 \mathrm{yr}$ (or $0-45$ yr at $68.4 \%$ confidence).

Table 1: Archaeological modelling of a hiatus between phase 1 and 2 in different models and the results of the sensitivity analysis. Significant interval durations (hiatus) are highlighted in grey (columns 3 and 4); non-overlapping of bounding dates of the end of phase 1 and the beginning of phase 2 (68.2\% level of confidence) are also highlighted in grey (columns 5 and 6). The position of simulated hiatus (IIIa1-IIIa6, IIIb3, and IIIc3) are shown in Figure 4.

\begin{tabular}{|c|c|c|c|c|c|}
\hline \multirow[t]{2}{*}{ Model } & \multicolumn{3}{|c|}{ Duration of Interval [years] } & \multicolumn{2}{|c|}{$\begin{array}{l}\text { 68.2\%-probability range of } \\
\text { phases [BC] }\end{array}$} \\
\hline & $\mu \pm \sigma$ & $68,2 \%$ & $95,4 \%$ & End I & Beginning II \\
\hline \multicolumn{6}{|l|}{ Archaeological modelling } \\
\hline \multicolumn{6}{|l|}{ Archaeologically justified hiatus } \\
\hline I (no modelling) & $35 \pm 26$ & $0-45$ & $0-86$ & $1162-1112$ & $1125-1075$ \\
\hline II (stratigraphical order) & $36 \pm 26$ & $1-46$ & $-2-88$ & $1162-1112$ & $1124-1074$ \\
\hline IIIa (two phases: uniform-prior) & $95 \pm 44$ & $52-145$ & $4-173$ & $1208-1137$ & $1094-1034$ \\
\hline IIIb (trapezoid prior) & $122 \pm 52$ & $74-166$ & $30-209$ & $1218-1153$ & $1091-1026$ \\
\hline IIIc (uniform and trapezoid prior) & $108 \pm 46$ & $60-155$ & $14-197$ & $1209-1145$ & $1093-1026$ \\
\hline \multicolumn{6}{|l|}{ Sensitivity analysis } \\
\hline \multicolumn{6}{|l|}{ Simulated, random hiatus $^{\dagger}$} \\
\hline IIIa1 (Bln-5477-KIA-18874) & $34 \pm 21$ & $0-47$ & $0-73$ & $889-845$ & $841-814$ \\
\hline IIIa2 & $26 \pm 19$ & $0-36$ & $0-64$ & $879-829$ & $837-808$ \\
\hline IIIa3 & $15 \pm 15$ & $0-20$ & $0-51$ & $835-803$ & $820-797$ \\
\hline IIIa4 & $25 \pm 20$ & $0-33$ & $0-66$ & $1007-963$ & $978-938$ \\
\hline IIIa5 & $26 \pm 20$ & $0-34$ & $0-66$ & $1385-1336$ & $1349-1310$ \\
\hline IIIa6 & $35 \pm 27$ & $0-45$ & $0-90$ & $1385-1298$ & $1323-1277$ \\
\hline IIIb1 & $3 \pm 0$ & $0-5$ & $0-5$ & $837-803$ & $872-799$ \\
\hline IIIb3 & $31 \pm 20$ & $6-41$ & $0-70$ & $854-810$ & $816-796$ \\
\hline IIIc1 & $40 \pm 25$ & $14-58$ & $3-78$ & $891-850$ & $840-814$ \\
\hline IIIc3 & $20 \pm 16$ & $0-25$ & $0-57$ & $907-828$ & $849-812$ \\
\hline \multicolumn{6}{|c|}{ Variation of measurement inaccuracy of radiocarbon ages } \\
\hline IIIa $(0.5 \sigma)$ & $79 \pm 36$ & $42-121$ & $7-143$ & $1187-1128$ & $1091-1040$ \\
\hline IIIa $(1.5 \sigma)$ & $110 \pm 52$ & |58-168 & 4-199 & 1247-1149 & $1108-1024$ \\
\hline IIIa $(2.0 \sigma)$ & $115 \pm 59$ & |50-178 & $0-217$ & |1238-1154 & $1102-1031$ \\
\hline
\end{tabular}


Calibration curve

\begin{tabular}{|l|l|l|l|l|l|}
\hline IIIa (Intca198) & $121 \pm 50$ & $76-182^{*}$ & $17-212^{*}$ & $1241-1155$ & $1082-1026$ \\
\hline IIIa (Intcal04) & $115 \pm 49$ & $72-174 *$ & $13-202^{*}$ & $1241-1161$ & $1096-1035$ \\
\hline IIII (Intcal09) & $116 \pm 49$ & $71-173^{*}$ & $16-204^{*}$ & $1242-1162$ & $1097-1034$ \\
\hline
\end{tabular}

For the second single-phase model - including Outlier, After, Phase, and Combine (Model II) - the time range of the end of the Late Bronze Age period is calculated to be $1162-1112 \mathrm{cal}$ BC at $68.4 \%$ confidence, and the beginning of the Transitional period to be 1124-1074 cal BC. The 95.8\% probability modelled age ranges are 1187-1077 and 1156-1041 cal BC, respectively. Although all ranges are overlapping (again), the modelled duration of the hiatus is significant at $68.4 \%$ confidence, ranging between 1 and $46 \mathrm{yr}$. At $95.8 \%$ confidence, the hiatus is nevertheless not significant, as its duration is estimated to be between -2 and $88 \mathrm{yr}$.

Explicitly modelling the two periods and assuming an abrupt end/beginning of the phases (Model IIIa), the ages of the marginal dates of the two periods are estimated to be in the $95 \%$ ranges 1208 1137 or $1132-1019 \mathrm{cal} \mathrm{BC}$, or $1208-1137$ and $1094-1034 \mathrm{cal} \mathrm{BC}$ at $68.4 \%$ confidence, respectively. The resultant $68.4 \%$ and $95.8 \%$ modelled duration ranges of the hiatus are 52-145 yr and 4-173 yr. Applying a trapezoid prior distribution, the duration of the hiatus is estimated to be between 30-209 $\mathrm{yr}$ at $95.8 \%$ confidence for Model IIIb (continuous end/beginning of the periods) or between 14 and 197 $\mathrm{yr}$ for Model IIIc (abrupt end of period 1/ continuous beginning of period 2). The resultant modelled age ranges for the marginal dates are shown in Table 1; none of the resultant ranges overlap at $68.4 \%$ confidence, but all ranges overlap at $95.8 \%$ confidence; modelling provided an age range the end of the Late Bronze Age period of 1246-1116 cal BCE and a age range of 1130-992 for the beginning of the Transitional period (Model IIIb).

The probability distributions of the phase boundaries at $68.2 \%$ and the $95.4 \%$ confidence are shown in Figure 4; their numerical representation is given in Table 1. The a-posteriori probabilities of the simulated phase boundaries do not overlap at $68.2 \%$ confidence distribution, while there is a slight overlap at a $95.4 \%$ level of confidence. At least at a level of confidence at $68.2 \%$ the hiatus hypothesis cannot be rejected. 


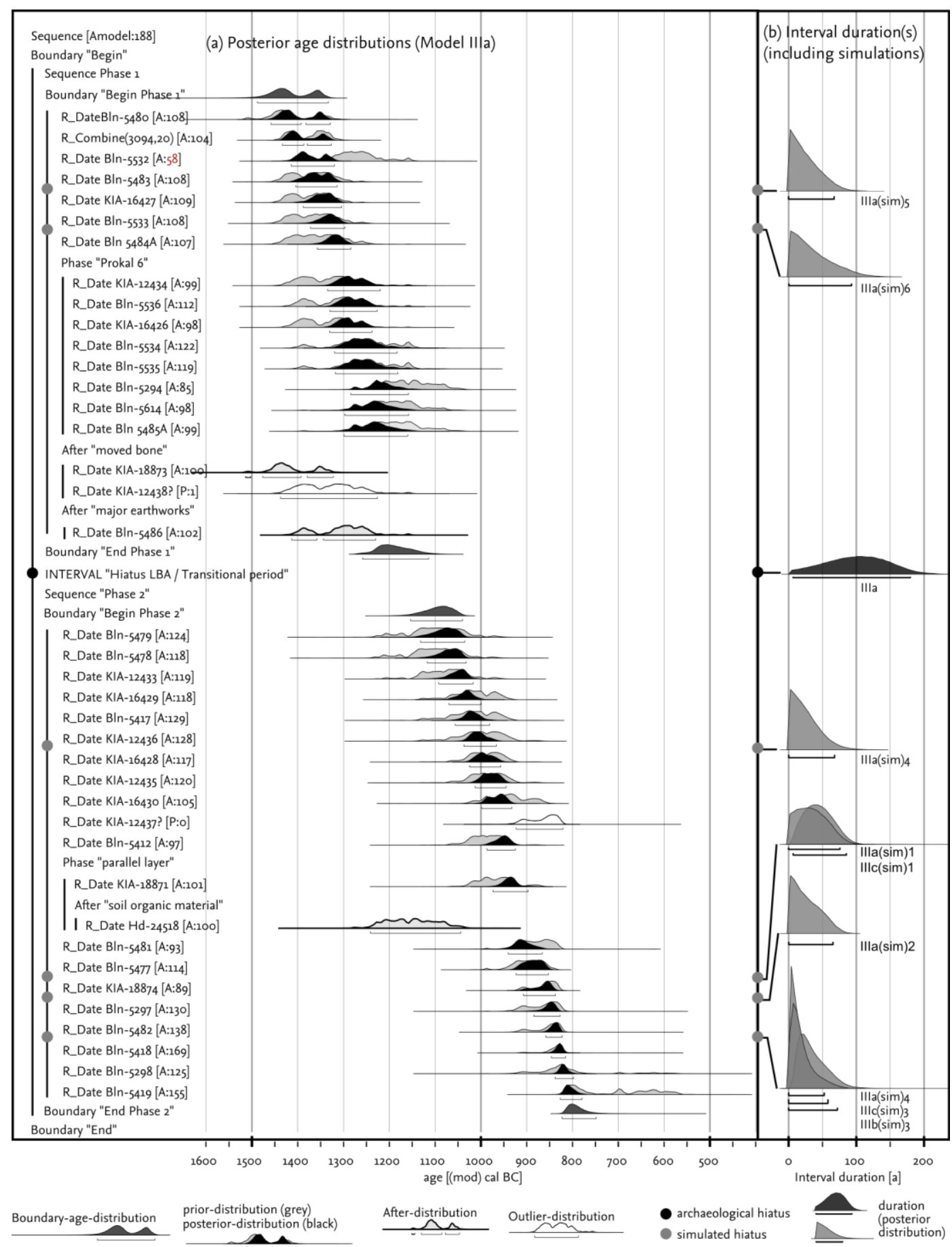

Figure 4: Prior and posterior age distributions of the main chronological model (IIIa), explicitly including the Late Bronze Age and the Transitional phase and the Interval-query. The position of the archaeological and the simulated hiatus are marked with dots; the posterior distributions of their durations are shown on the right.

In addition, besides determining the boundaries by arguing with the extreme values of the two phases, an explicit Interval query is implemented. The results for the determination of the duration of the interval, i.e. the hiatus, in different models are shown in Table 1. The hiatus is significant at a probability of $68.2 \%$ or even $95.4 \%$ (Table 1 , Figure $4 b$ ).

This is also the case if the two phase hypothesis is not included in the model as a prior assumption. Its mathematical duration is between 1 and $46 \mathrm{yr}$. Figure $4 \mathrm{~b}$ shows the significance and duration of the 
hiatus in the different models: on the one hand, including the assumption of two explicit phases (Models IIIa-c), and on the other hand - based on a simple, modelled sequence of ${ }^{14} \mathrm{C}$ dates without separation of phases (Models I and II). The graph in Figure 4b shows the probability density function. Summarizing, in all models with explicit implementation of two phases (Models II and IIIa-c), the hiatus between them is significant at the $95.4 \%$ probability range $( \pm 2 \sigma)$. In Model I (modelled data sequence without separate phases), the hiatus is significant only in the $68.2 \%$ probability range $( \pm 1 \sigma)$. Thus, a hiatus between phase 1 and 2 is probable in all models, with varying level of significance. To assess the reliability of the obtained models, they were subjected to a comprehensive sensitivity analysis (Table 1).

\section{DISCUSSION}

\subsection{The chronology of the beginning and the end of the Chicha settlement ${ }^{5}$}

The Late Bronze Age and the Transitional period complexes in Chicha are clearly distinct from those of the later Early Iron Age. As a result of modelling the data the calibrated age of those periods has changed. Initially (Model 0), the age ranges of the Chicha samples covered a time span from $1389 \pm 49$ cal BC (Bln-5480) to $692 \pm 86$ cal BC (Bln-5419). Depending on the model, the calibrated dates of these two samples vary. In Model I, the first date (Bln-5480) refers to $1421 \pm 19 \operatorname{modBC}$, in Model II to $1409 \pm 20$ modBC. The second date (Bln-5419) in Model I refers to $670 \pm 84 \operatorname{modBC}$ and Models II to $781 \pm 14$ modBC, respectively. In Models III a-c the age of the oldest sample (Bln-5480), as compared to non-modelled age, is slightly younger (Model IIIa: $1378 \pm 38$ modBC) or slightly older, respectively (Model IIIb: 1390 \pm 35 modBC and Model IIIc: $1394 \pm 34$ modBC). While the age of the modelled latest sample (Bln-5419) is older in all cases (IIIa: $783 \pm 12 \bmod$ BC; IIIb: $777 \pm 21 \operatorname{modBC}$; IIIc: $777 \pm 19$ modBC). Thus, in various models, the probable moment of the beginning of the settlement in Chicha falls within $15^{\text {th }}-14^{\text {th }} \mathrm{c}$. BC, while the probable age of the end of the activity in the second stage can be dated to the $8^{\text {th }} \mathrm{c}$. BC.

\subsection{Model quality - sensitivity analysis}

A hypothesised hiatus between the Late Bronze Age period 1 and the Transitional period 2 is significant at 68.2 and $95.4 \%$ confidence based on the OxCal Interval-query. In addition, the $a$ posteriori probability distributions of the outer dates of the periods do not overlap. The outer dates and the Interval criterion were used in other studies as suitable for hiatus detection (Riedle and Edinborough 2012, Wardle et al. 2014, and Hamilton 2010, respectively), even at lower levels of significance (Dye 2011, Barchard 2008). Nevertheless, the significance of the Chicha-hiatus might be a result of model sensitivity. Based on the prior information of Model IIIa, the test of significance for the uncalibrated ${ }^{14} \mathrm{C}$ measurements shows a slight variability of the hiatus duration, being estimated to ranges from 4-173 years at $95.8 \%$ when halving the laboratory error, to 4-199 years when multiplying the error by 1.5 and to $0-217 \mathrm{yr}$ when doubling the error. In the latter case, the hiatus is not significant. A systematic error in the age estimation by \pm 40 and $-80 \mathrm{yr}$ would not affect the significance of the hiatus, whereas an error of $+80 \mathrm{yr}$ would result in a non-significant hiatus. Nevertheless, such large systematic errors are not known from the laboratories involved (Berlin, Bln, and Kiel, KI) and might not influence the model quality. The hiatus is significant for all applied calibration curves.

There are dates with an agreement index $\mathrm{A}<60 \%$ integrated in the model. Due to their stratigraphical position and the distance to the hypothesised hiatus, the relatively low agreement might not have an influence on the overall significance of the hiatus. In addition, the agreement of the entire model is greater than $60 \%$.

\footnotetext{
${ }^{5}$ We consider the period from the Late Bronze Age up to the Transitional period to the Early Iron Age.
} 
A sensitivity analysis of the stratigraphical prior assumptions was not applied as specific model as the stratigraphy has been discussed elsewhere (Schneeweiss 2007, Molodin et al. 2008b). Different possible intensities of activity during the two settlement phases under estimation are included in the sensitivity analysis by applying different prior distributions of activity (uniform prior, trapezoid prior, and a trapezoid prior with a sudden end of the Late Bronze Age period). The selection of theses priors changed the duration of the hiatus, but not its significance.

The most important aspect of the significance analysis is the integration of simulated (artificial) hiatus in the models. The shortest simulated hiatus in Model IIIa has a duration of 0-47 yr (at 95.8\% confidence, IIIa1), the longest hiatus a duration of 0-90 yr (IIIa6). Thus, these simulated hiatus are not significant. Also in model IIIb, no simulated hiatus is significant at $95.8 \%$ confidence (only in Model IIIb3, the simulated hiatus is significant at $68.2 \%$ confidence, having a duration of 6-41 yr). One of the simulated hiatus in Model IIIb is significant at $95.8 \%$ confidence, having a duration of 3-78 yr (Model IIIc3). Nevertheless this simulated hiatus is much shorter than the archaeological validated hiatus in the same model, where the hiatus has a duration of $108 \pm 46 \mathrm{yr}$ (a fact that is clearly shown in Figure $4 \mathrm{~b}$ ). Thus, the sensitivity analysis, including the simulations, is useful to verify that the archaeological verified is not only significant, but also not sensitive to uncertainties in prior assumptions or a random product of modelling.

\subsection{Circular argument of Bayesian statistics and modelling?}

With regard to the results of the chronological modelling for the settlement phases of Chicha, a circular argument can be illustrated by Figure 5, showing the different A-posteriori-probabilities of the youngest date of phase $1(\mathrm{~B} \ln -5485 \mathrm{~A})$, and the oldest date of phase $2(\mathrm{~B} \ln -5479)$ with (Figure 5c) and without (Figure $5 \mathrm{~b}$ ) of a two phase assumption in the model and the calibrated, unmodelled ages (Figure 5a). Using the OxCal Sequence function (i.e., a condition specifying the sequence of events) to model the Late Bronze Age and the Transitional Period explicitly (Figure 5c), the older date is getting older and the younger date even younger. It is obvious that the archaeological assumption of the two phases favours the archaeological argumentation and the verification of the hiatus hypothesis.

In literature, this problem is known as "algorithm artefact" (Weninger et al., 2010). It essentially means that chronological models, indeed, provide precise data (which is also true for the Chicha data), but with lower accuracy. Therefore Weninger et al. (2010) consider the implementation of archaeological information in mathematical distributions as a critical point when using Bayesian statistics for chronological modelling. This problem can be avoided by varying the assumptions (Weninger et al. 2010), in our case by simulating artificial hiatus. Bayliss et al. (2007) used a similar approach when they calculated several models with different distribution assumptions.

However, the simulations in the course of sensitivity analysis for the Chicha data clearly show that a hiatus is only significant, if it is archaeologically justified. Artificially simulated hiatus are significant only in one of ten models. Thus, the a priori assumption of multiple phases clearly affect the $a$ posteriori probabilities of the data in comparison to the a-priori probabilities (Figure 5), but a significant hiatus can be modelled only at an archaeologically sound position in the sequence, and not at an artificial position of a simulated hiatus. In addition, the use of different priors (uniform-prior, trapezoid prior or a combination of both) does not reduce the significance of the hiatus (Table 1). 


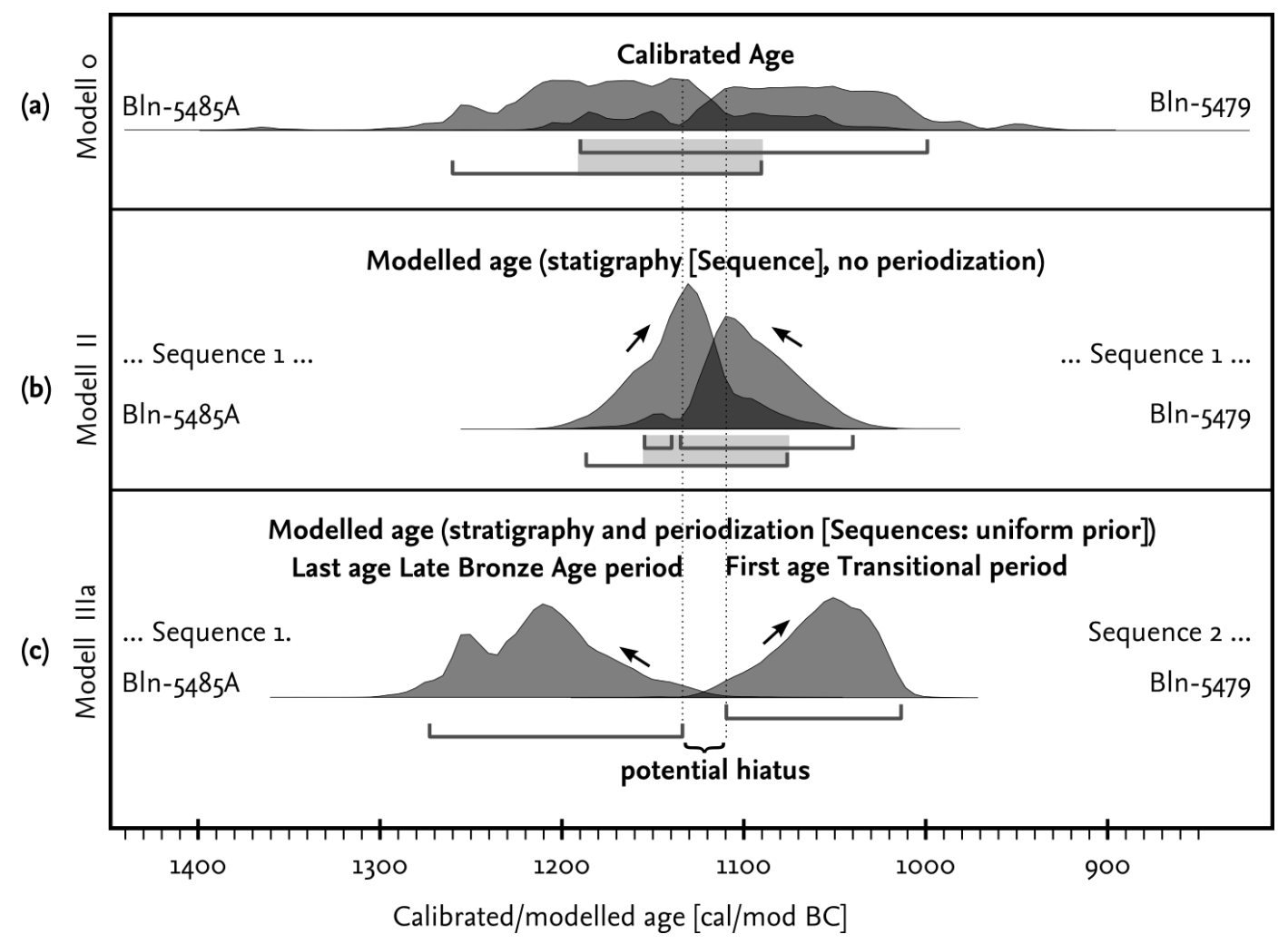

Figure 5: The effect of archaeological prior information on posterior age distributions of the last age in the Late Bronze Age period (Bln-5485A) and the first age in the Transitional Period (Bln-5479). 95.4\%-confidence levels are given below the distributions; arrows mark the postponement of the posterior distributions after modelling. The potential (archaeologically justified) hiatus (as modelled in model IIIa, [c]) is marked with dashed vertical lines.

\subsection{The absolute chronology of the Transitional period}

Regular and fortified large-scale settlements as Chicha are considered to be typical for the transitional period from Bonze Age to Iron Age in the forest-steppe of Western Siberia (Molodin 2006, Molodin and Parzinger 2006, Schneeweiß 2010). Arguing with the Chicha case they were believed to be a result of a continuous evolutional process triggered by climatic changes (Molodin 2006, 2008, 2010). Modelling the absolute chronology of Chicha, in contrast, does support the existence of a hiatus between settlement phases 1 and 2, which implies that the new big regular settlement of phase 2 was established on the site of an older, abandoned Late Bronze Age settlement. Furthermore the sudden appearance of this early protourban settlement type, obviously, was not directly connected to the early nomads in the Southern Siberian steppes, as was believed earlier (e.g. Parzinger 2006, Molodin 2009, Schneeweiß 2010), since the radiocarbon data shows that the regular settlement was already established probably in the $11^{\text {th }} / 10^{\text {th }} \mathrm{c}$. $\mathrm{BC}$, what is somewhat prior to the appearance of the early nomads in the $9^{\text {th }} \mathrm{c}$. BC.

In addition, the data is suggesting that the settlement was continuously used during the phase 2 until the $8^{\text {th }}$ or even $7^{\text {th }}$ c. BC, i.e. over several centuries. Such a long period of site utilization seems to contradict, at a first glance, the archaeological evidence, as there are only rare features showing reconstructions or stratigraphical overlapping, respectively, especially in the peripheral area of the settlement. As the archaeological evidence so the strikingly regular settlement plan in the magnetogram is suggesting as well a relatively short occupation period of the settlement. However, this dilemma can be solved when considering several essential moments. 
Firstly, a differentiated consideration of the radiocarbon data allows to recognize several subphases within the phase 2 , concentrating primarily in the $11^{\text {th }}, 10^{\text {th }}$ and $9^{\text {th }} / 8^{\text {th }} \mathrm{c}$. BC. The two isolated youngest dates Bln-5418 and Bln-5419 probably reflect an additional subphase in $8^{\text {th }} / 7^{\text {th }} \mathrm{c}$. BC, which could be underrepresented in the radiocarbon data series (Appendix 1). It happens, in particular, that all data which can be used for dating the dwelling features of phase $2^{6}$ belong to the $11^{\text {th }}$ and mainly $10^{\text {th }} \mathrm{c}$. BC (Appendix 1). Therefore, they are probably reflecting an older horizon within the phase 2, while all data which represent a younger horizon in the $9^{\text {th }}-8^{\text {th }} / 7^{\text {th }} \mathrm{c}$. BC, exclusively originate from bone or charcoal samples from objects, which obviously found their way into the half-sunken dwellings only after their abandonment ${ }^{7}$, if not originating from fillings of the moats (Appendix 1$)^{8}$. In all cases, those objects are large accumulations of bones and potsherds, which could hardly be associated with a regular use of the dwellings. It is worth recalling that objects from sunken dwellings can be considered as closed find complex only in exceptional and well-argued cases (e.g. Gryaznov 1956, 53, Matveev 1993, 85-86, Schneeweiß 2007, 83-84). Moreover, it becomes clear that the full extent of the regular settlement ("Periphery") was already achieved in the older subphase of phase 2 . This correlates with the idea, based on the magnetogram, that the regular large settlement was erected within a relatively short time which, apparently, corresponds with the Transitional period from the Late Bronze Age to the Early Iron Age and can be attributed to the $11^{\text {th }}$ and $10^{\text {th }} \mathrm{c}$. BC. The later horizon of phase 2 suggests a further utilization of the settlement in the $9^{\text {th }}-8^{\text {th }} / 7^{\text {th }} \mathrm{c}$. BC. However, at the moment no dwellings can be clearly assigned to this narrower period.

Secondly, the remarkable variability of forms, ornamentations and cultural affiliation of the phase 2 pottery (Molodin and Mylnikova 2004, Schneeweiß 2007, 41-107, 103-106, 269-271), which were thought to be synchronous, could be explained obviously to a certain extent by chronological differences. Typological analysis revealed clear connections of the Chicha phase 2 pottery with ceramic complexes from a number of regions of the Western Siberian forest steppe and adjacent southern and northern regions (Schneeweiß 2007, Molodin et al. 2008a, 2008b, 2009a, 2009b). Different attempts to interpret this situation failed to be convincing. On the one hand, the general explanation of the phase 2 as belonging to the archaeological Krasnoozero culture of the Middle Irtysh region (Schneeweiß 2007, 212-214) was criticized as too limited (Molodin and Parzinger 2009, 71). On the other hand, the interpretation of Chicha as a central trading place with inhabitants of different cultures living together seems to underestimate to a certain extent the chronological stratification of the data (e.g. Molodin et al. 2008a, 2009a). A correlation of different ceramic traditions of Chicha phase 2 with different chronological subphases, as argued above, might offer a compromise and more plausible explanation for the aforementioned apparent contradiction between the geomagnetic picture and the archaeological evidence.

The detailed typological analysis of the small finds from Chicha (Molodin and Parzinger 2009) not only clarified the chronology of the Late Bronze Age (Irmen culture) settlement in phase 1, but primarily revealed close parallels of the Chicha phase 2 finds to the first (Bajnov) stage of the Tagar culture in the Minusinsk Basin (ca. $9^{\text {th }}$ c. BC), as well as to the following Early Scythian cultures of nomadic horsemen in Southern Siberia (Arzhan 2, ca. $7^{\text {th }}$ c. BC). These typologically identified connections largely correspond with the radiocarbon data from Chicha and from Southern Siberia (Görsdorf et al. 2001, Schneeweiß 2007, Svyatko et al. 2009). Therefore, the regular protourban settlement of Chicha is likely to be attributed mainly to the relatively short Transitional period in the $11^{\text {th }} / 10^{\text {th }}$ c. BC. From the $9^{\text {th }}$ c. BC onwards, in the following Early Iron Age period, a probably nomadic population reused the dwelling pits to a certain extent. A nearby nomadic burial complex

\footnotetext{
${ }^{6}$ BIn-5479, BIn-5478, KIA 12433, KIA 16429, BIn-5417, KIA 12436, KIA 16428, KIA 12435, KIA 16430.

${ }^{7}$ BIn-5477, Bln-5297, BIn-5482, BIn-5298, BIn-5418, Bln-5419.

${ }^{8}$ KIA 12437, BIn-5481, KIA 18874.
} 
(Zdvinsk 1) supports the interpretation of their nomadic lifestyle (Molodin 2006). It is likely, that this Iron Age nomadic population used a certain pottery type, which was described first while analysing the pottery complex from Chicha (Molodin et al. 2004, 275, Schneeweiß 2007, 36-3799), and later named "Berlik culture" (Molodin 2008). The bearers of the Berlik culture could be the latest inhabitants of the phase 2 in the $8^{\text {th }} / 7^{\text {th }} \mathrm{c}$. BC. In another perspective, the discovery of Berlik type sherds in the "Citadel" area gave reason for their dating to the $9^{\text {th }} \mathrm{c}$. BC (Molodin 1985, 2015).

\section{Conclusions}

The main focus of this paper is the quantitative and qualitative estimation of the probability of a possible hiatus between two settlement phases in Chicha, using Bayesian statistics and chronological modelling for the revaluation of the radiocarbon data from this site. The archaeological evidence for the existence of a hiatus is based on stratigraphical observations, pottery typology, analysis of burial rituals and differences in subsistence economy between the Late Bronze Age and Transitional period populations.

The following conclusions can be drawn as the result of the absolute chronology modelling for Chicha. The archaeologically validated hiatus between the Late Bronze Age and the Transitional period is (a) not visible in the unmodelled, calibrated dates and is (b) not significant in a chronological sequence without explicitly modelling two phases of activity. The implementation of (c) the archaeological prior assumption of two phases leads to the significance of a modelled hiatus. As the hiatus does not necessarily follow from the unmodelled radiocarbon data it cannot be considered as primary for the model. Finally, all chronological models using Bayesian statistics have the problem of a circular argumentation of the original archaeological hypothesis. In the case of Chicha chronology, this problem could be avoided by sensitivity analysis of the modelling — simulated hiatus are almost all not significant.

Summing up, Bayesian statistics and chronological modelling proved to be an efficient tool for estimating a supposed hiatus and for a certain specification of phases in radiocarbon data series. The confirmation of a hiatus in the development of the Chicha settlement, the evaluation of its chronological extent, as well as assessing of other existing data permit to look at cultural processes of the Transitional period in another perspective. The probably main implication of an interruption in the development of the Chicha is that there was no continuous evolution from the Late Bronze Age to the protourban settlement type of the Transitional period. These large regular sites, obviously, appear suddenly and do not function very long; they probably remain restricted to the Transitional period at the very turn of the $2^{\text {nd }}$ to $1^{\text {st }}$ mil. BC. The profound cultural changes on all archaeologically recognisable levels suggest a complete change of population in comparison to the previous Bronze Age. The alteration to the following Iron Age was associated again with significant cultural changes. The population was from then on nomadic. It replaced - or absorbed - the former "protourban" inhabitants of the Transitional period in the forest-steppe zone. The nomads show clear cultural connections to the Southern adjacent steppe regions.

Notwithstanding the good results for the chronological framework, there are still many open questions concerning the reasons, function, character, cultural background, protagonists and end of the protourban settlements and the Transitional period of Western Siberia to be discussed, since most of the existing interpretations and models do not correspond to the presented chronological results.

\footnotetext{
${ }^{9}$ This type of pottery was difficult to date. It was then correlated with a so called "phase $3 a$ ", which could be
} dated approximately to the first half or the middle of the $1^{\text {st }}$ mil. BC. 


\section{Acknowledgements}

This work has been supported by the Ministry of Education and Science of the Russian Academy of Sciences, grant 14.Z50.31.0010 (project "The Earliest Colonization of Siberia: Formation and Dynamics of the North Asian Cultures"). Jens Schneeweiß is Feodor Lynen Research Fellow of the Alexander von Humboldt Foundation. Fabian Becker is scholarship holder within the Cluster of Excellence TOPOI.

\section{References}

Arslanova FK. 1974. Pogrebalnyi kompleks VIII-VII vv. do n.e. iz Vostochnogo Kazakhstana [Burial complex of VIII-VII centuries BC from Eastern Kazakhstan]. In: Akishev KA, editor.V glub vekov. Alma-Ata: Nauka Kazakhskaya SSR Publishing. p 46-60. In Russian.

Bachand BR. 2008. Bayesian refinement of a stratified sequence of radiometric dates from Punta de Chimino, Guatemala. Radiocarbon 50(1):19-51.

Bayliss A. 2009. Rolling out Revolution: Using radiocarbon dating in archaeology. Radiocarbon 51(1):123-47.

Bayliss A, Bronk Ramsey C, van der Plicht J, Whittle A. 2007. Bradshaw and Bayes: towards a timetable for the Neolithic. Cantab. Archaeological Journal 17:1-28.

Becker H, Fassbinder JWE. 1999. Magnetometry of a Scythian Settlement in Siberia near Chicha in the Baraba Steppe 1999. In: JWE Fassbinder, WE Irlinger, editors. Archaeological Prospection. Arbeitshefte des Bayerischen Landesamtes für Denkmalpflege. Volume 108. München: Bayerisches Landesamt fur Denkmalpflege. p 168-72.

Becker F, Schneeweiß J. 2016. Zur absoluten Chronologie der westsibirischen Spätbronzeund frühen Eisenzeit. Die Überprüfung der Besiedlungsphasen in Čiča mit Bayes'scher Statistik. Prähistorische Zeitschrift 91. In press.

Borzunov VA. 1992. Zaurale na rubezhe bronzovogo i zheleznogo vekov [Trans-Urals on the border of Bronze and Iron Ages]. Ekaterinburg: Ural University Publishing. 188 p. In Russian.

Bronk Ramsey C. 1994. Analysis of chronological information and radiocarbon calibration: the program OxCal. Archaeological Computing Newsletter 41:11-6.

Bronk Ramsey C. 1995. Radiocarbon calibration and analysis of stratigraphy: The OxCal program. Radiocarbon 37(2):425-30.

Bronk Ramsey C. 1998. Probability and dating. Radiocarbon 40(1):461-74.

Bronk Ramsey C. 2008. Deposition models for chronological records. Quaternary Science Review 27:42-60.

Bronk Ramsey C. 2009. Bayesian analysis of radiocarbon dates. Radiocarbon 51(1): 337-60.

Bronk Ramsey C, Lee S. 2012. Development and application of the Trapezoidal Model for archaeological chronologies. Radiocarbon 54 (1):107-22.

Bronk Ramsey C, Manning SW, Galimberti M. 2004. Dating the Volcanic Eruption at Thera. Radiocarbon 46(1):325-44.

Buck CE, Cavanagh WG, Litton C. 1996. Bayesian approach to interpreting archaeological data. Statistics in practice. Chichester : Wiley.

Buck CE, Christen JA, James GN. 1999. BCal: an on-line Bayesian radiocarbon calibration tool. Internet Archaeology 7.

Buck CE, Litton CD, Smith AFM. 1992. Calibration of radiocarbon results pertaining to related archaeological events. Journal Archaeological of Science 19(5):497-512. 
Buck CE, Menson B. 2015. On being a good Bayesian. World Archaeology 45(4):567-84.

Chlenova NL. 1994. Pamyatniki kontsa epokhi bronzy v Zapadnoi Sibiri [The archaeological sites of late Bronze Age in Western Siberia]. Moscow: Nauka Publishing. 170 p. In Russian.

Christen JA. 1994. Summarizing a set of radiocarbon determinations: a robust approach. Journal of the Royal Statistical Society Series C (Applied Statistics) 43(3):489-503.

Christen JA, Clymo RS, Litton CD. 1995. A Bayesian approach to the use of ${ }^{14} \mathrm{C}$ dates in the estimation of the age of peat. Radiocarbon 37(2):431-42.

Dye TS. 2011. A model-based age estimate for Polynesian colonization of Hawai'i, Archaeology in Oceania 46:130-8.

Friedrich W, Kromer B, Friedrich M, Heinemeier J, Pfeiffer T, Talamo S. 2006. Santorini eruption radiocarbon dated to 1627-1600 BC. Science 312:548.

Friedrich W, Kromer B, Friedrich M, Heinemeier J, Pfeiffer T, Talamo S. 2014. The olive branch chronology stands irrespective of tree-ring counting. Antiquity 88:274-7.

Görsdorf J. 1990. Die Interpretation von ${ }^{14} \mathrm{C}$-Datierungen im Berliner ${ }^{14} \mathrm{C}$-Labor. Zeitschrift für Archäologie 24:27-34.

Görsdorf J. 2000. Datierungen im Berliner ${ }^{14} \mathrm{C}$-Labor. Berliner Beiträge zur Archäometrie 17: 121-31.

Görsdorf J, Parzinger H, Nagler A, Leont'ev N. 1998. Neue ${ }^{14} \mathrm{C}$-Datierungen für die sibirische Steppe und ihre Konsequenzen für die regionale Bronzezeitchronologie. Eurasia Antiqua $4: 73-80$.

Görsdorf J, Parzinger H, Nagler A. 2001. New radiocarbon dates of the North Asian steppe zone and its consequences for the chronology. Radiocarbon 43(2B):1115-20.

Griffiths S. 2014. Simulations and Outputs. Radiocarbon 56(2):871-76.

Gryaznov MP. 1956. Istoriya drevnikh plemen Verkhnei Obi po raskopkam bliz s. Bolshaya Rechka [History of ancient tribes of Upper Ob River basin by excavation near settlement Bolshaya Rechka]. Materialy i Issledovaniya po Arkheologii SSSR 48. 228 p. In Russian.

Ermolaeva AS. 1985. Issledovaniya v Vostochnom Kazakhstane na levom beregu Irtysha [Researches in Eastern Kazakhstan on the left coast of Irtysh River]. Arkheologicheskie otkrytiya 1983 goda. Mocsow: Nauka Publishing. p 509-10. In Russian.

Hamilton WD. 2010. The use of radiocarbon and Bayesian Modelling to (Re)Write Later Iron Age settlement histories in East-Central Britain. Diss, Univ. Leicester. Unpublished PhD Thesis.

Höflmayer F. 2012. The date of the Minoan Santorini eruption: quantifying the "Offset". Radiocarbon 54(3-4):435-44.

Karlsberg AJ. 2006. Flexible Bayesian methods for archaeological dating. Diss. Univ. Sheffield, U.K. Unpublished PhD Thesis.

Khabdulina MK. 1986. Pogrebalnyi obryad naseleniya rannego zheleznogo veka Severnogo Kazakhstana (VIII-II vv do n.e.) [Burial practice of the Early Iron Age population in Northern Kazakhstan (VIII-II centuries BC)]. In: Zdanovich GB, editor. Chelyabinsk: Bashkir State University Publishing. 3-25 p. In Russian.

Kosarev MF. 1987. Epokha bronzy i perekhodnoe ot bronzovogo veka k zheleznomu [Bronge Age and Transition period from Bronze Age to Iron Age]. Epokha bronzy lesnoi polosy SSSR. Moscow: Nauka Publishing. p 289-304. In Russian. 
Margulan AK. 1979. Begazy-Dandybaevskaya kultura Tsentralnogo Kazakhstana [BegazyDandybai Culture of Central Kazakhstan]. Alma-Ata: Nauka Kazakhskaya SSR Publishing. 360 p. In Russian.

Matveev AV. 1993. Irmenskaya kultura v lesostepnom Priobe [Irmen Culture in forest-steppe area of the Ob River basin]. Novosibirsk: Novosibirsk State University Publishing. 180 p. In Russian.

Molodin VI. 1979. Nekotorye problemy perekhodnogo ot bronzy k zhelezu vremeni v Novosibirskom Priobe [Some issues of Transitional period from Bronze Age to Iron Age in Novosibirsk area of the Ob River basin]. Problemy skifo-sisbirskogo kulturno-istoricheskogo edinstva. Kemerovo. $\mathrm{p}$ 110-12. In Russian.

Molodin VI. 1985. Baraba v epokhu bronzy [Baraba area in the Bronze Age]. Novosibirsk: Nauka Publishing. 200 p. In Russian.

Molodin VI. 2006. The necropolis of Chicha 1 and the burial rite of Late Bronze to Early Iron Age peoples of the Baraba forest-steppe zone. Archaeology, Ethnology and Anthropology of Eurasia. 4 (28):115-21.

Molodin VI. 2006. Spetsiphica etnokulturnykh i khozyaistvennykh yavlenii na pamyatnike perekhodnogo ot bronzy k zhelezu vremeni Chicha 1 (Baraba, Zapadnaya Sibir): veroyatnaya model [Specifics of ethno-cultural and economy phenomena on the Transitional from Bronze Age to Iron Age Chicha 1 site (Baraba, Western Siberia): probability model] // Proizvodstvennye tsentry: istochniki, "dorogi”, areal rasprostraneniya. Sankt-Peterburg: Sankt-Petersburg State University Publishing. p 171-75. In Russian.

Molodin VI. 2008. Periodizatsiya, khronologiya i kulturnaya identifikatsiya pamyatnika Chicha (Barabiskaya lesostep) [Periodization, chronology and cultural identification of the Chicha site (Baraba forest-steppe)]. Vremya $i$ kultura $v$ arkheologo-etnografiches issledovaniyakh drevnikh $i$ sovremennykh obshchestv Zapadnoi Sibiri $i$ sopredelnykh territorii: Problemy interpretatsii i rekonstruktsii. Tomsk: Tomsk State University Publishing. p 155-63. In Russian.

Molodin VI. 2010. Ekologicheskii "stress" na rubezhe II-I tys. do n.e. i ego vliyanie na etnokulturnye i sotsialno-ekonomicheskie protsessy u narodov Zapadnoi Sibiri [Ecological "stress" on the turn of II-I mil. BC and its influence on ethno-cultural and socio-economical processes of peoples of Western Siberia]. Kultura kak sistema $v$ istoricheskom kontekste. Opyt Zapadno-Sibirskikh arkheologo-ethograficheskikh soveshchanii. Tomsk: Agraf-Press Publishing. p 22-4. In Russian.

Molodin VI. 2015. Berlikskaya kultura v zapadnosibirskoi lesosstepi [Berlik Culture in Western Siberia forest-steppe]. Arkheologiya Zapadnoi Sibiri $i$ Altaya: opyt mezhdistsiplinarnykh issledovanii. Barnaul: Altai State University. p 237-44. In Russian.

Molodin VI, Epimakhov AV, Marchenko ZV. 2014. Radiouglerodnaya khronologiya kultur epokhj bronzy Urala i yuga Zapadnoi Sibiri: printsipy i podkhody, dostizheniya i problemy [Radiocarbon chronology of the Bronze Age Urals and south Western Siberia Cultures: principals and approaches, achievements and problems]. Vestnik Novosibirskogo Gosudarstvennogo Universiteta. Seriya istoriya, filologiya. Tom 13, Vypusk 3. Arkheologiya i etnografiya. p 136-67. In Russian.

Molodin VI, Marchenko ZV, Kuzmin YV, Grishin AE, van Strydonck M, Orlova LA. 2012. ${ }^{14} \mathrm{C}$ chronology of burial grounds of the Andronovo period (Middle Bronze Age) in Baraba forest steppe, Western Siberia. Radiocarbon 54(3-4):737-47.

Molodin VI, Mylnikova LV. 2004. Keramika gorodishcha Chicha kak istochnik po istorii 
perekhodnogo ot bronzy $\mathrm{k}$ zheleznomu veku [Ceramics of Chicha fortified settlement as a sources on the history of Transitional period from Bronze Age to Iron Age]. Istoriya $i$ kultura Sibiri $v$ issledovatelskom $i$ obrazovatelnom prostranstve. Novosibirsk: NPSU Publishing. $\mathrm{p}$ 101-6. In Russian.

Molodin VI, Mylnikova LN, Durakov IA, Kobeleva LS. 2008a. Kulturnaya prinadlezhnost gorodishcha Chicha 1 (po dannym statistico-planigraficheskogo izucheniya keramicheskih kompleksov) [Cultural identification of Chicha 1 fortified settlement (on the statistic and planigrafic data of the studying of ceramics complexes)]. Trudy II (XVIII) All-Russian arkheologicheskogo Sezda. Tom I. Moscow: Institute of Archaeology RAS Publishing. p 42530. In Russian.

Molodin VI, Mylnikova LN, Durakov IA, Kobeleva LS. 2009a. Kulturnaya prinadlezhnost gorodishcha Chicha 1 po dannym statistic-planigraficheskogo izucheniya keramicheskikh kompleksov na raznykh uchastkakh pamyatnika [Cultural identification of Chicha 1 fortified settlement on the statistic and planigrafic data of the studying of ceramics complexes on the different parts of sites]. In: Molodin VI, Parzinger H, editors. Chicha - gorodishche perekhodnogo ot bronzy $k$ zhelezu vremeni $v$ Barabinskoi lesostepi. Tom 3. NovosibirskBerlin: IAET SB RAS Publishing. p 44-50. In Russian.

Molodin VI, Mylnikova LN, Durakov IA, Kobeleva LS. 2009b. Sinkretichnaya keramika gorodishcha Chicha 1 [Syncretic ceramic of the Chicha 1 fortified settlement]. In: Tairov AD, Ivanova NO, editors. Etnicheskie vzaimodeistviya na Yuzhnom Urale. Chelyabinsk: SouthUrals State University Publishing. p 73-8. In Russian.

Molodin VI, Mylnikova LN, Kobeleva LS. 2008b. Stages in the settlement history of Chicha 1: the results of ceramic analysis. Archaeology, Ethnology and Anthropology of Eurasia. 3 (35):54-67.

Molodin VI, Parzinger G. 2006. Issledovaniya pamyatnika Chicha v Barabinskoi lesostepi (itogi, perspectivy, problemy) [Researches of the Chicha site in Baraba forest-steppe (results, prospects, problems)]. In: Derevyanko AP, Molodin VI, editors. Sovremennye problem arkheologii Rossii. Tom 1. Novosibirsk: IAET SB RAS Publishing. p 49-55. In Russian.

Molodin VI, Parzinger G. 2009. Khronologiya pamyatnika Chicha 1 [Chronology of Chicha 1 site]. In: Molodin VI, Parzinger G, editors. Chicha - gorodishche perekhodnogo ot bronzy $k$ zhelezu vremeni $v$ Barabinskoi lesostepi. Tom 3. Novosibirsk-Berlin: IAET SB RAS Publishing. p 51-77. In Russian.

Molodin VI, Parzinger G, Becker G, Fassbinder J, Chemyakina MA, Nagler A, Neef R, Novikova OI, Manshtein AK, Garkusha YN, Grishin AE, Efremova NS. 1999. Arkheologogeofizicheskie issledovaniya rossiisko-germaskoi ekspeditsii $\mathrm{V}$ Barabinskoi lesostepi [Archaeology-geophysical investigations of Russian-Germany expedition in Baraba foreststeppe]. In: Derevyanko AP, Molodin VI, editors. Problemy arkheologii, etnografii, antropologii Sibiri i sopredel'nykh territorii. Tom 5. Novosibirsk: IAET SO RAN Publishing. p 454-61. In Russian.

Molodin VI, Parzinger H, Garkusha YN, Schneeweiss J, Becker H, Fassbinder J, Chemiakina MA, Grishin AE, Novikova OI, Efremova NS, Manstein AK, Diadkov PG, Vasiliev SK, Mylnikova LN, Balkov EV. 2001a. Archaeological and geophysical investigations carried out by the joint Russian-German expedition at the Bronze-Iron Age settlement of Chicha in the Baraba steppe. Preliminary results. Archaeology, Ethnology and Anthropology of Eurasia 3(7):104-27.

Molodin VI, Parzinger G, Garkusha YN, Schneeweiss J, Grishin AE, Novikova OI, Efremova NS, Chemyakina MA, Mylnikova LN, Vasilev SK, Becker G, Fassbinder J, Manshtein AK, 
Dyadkov PG. 2001b. Chicha - gorodishche perekhodnogo ot bronzy $k$ zelezu vremeni v Barabinskoi lesostepi. Pervye resultaty issledovanii [Chicha - fortified settlement of Transition period from Bronze Age to Iron Age in Baraba forest-steppe. First results]. Materialy po arkheologii Sibiri. Vypusk 1. Novosibirsk: IAET SO RAB Publishing. 240 p. In Russian.

Molodin VI, Parzinger G, Garkusha YN, Schneeweiss J, Novikova OI, Chemyakina MA, Mylnikova LN, Efremova NS, Grishin AE Marchenko ZV, Rybina EV. 2002a. Rezultaty polevykh issledovanii gorodishcha Chicha 1 [Results of field studies on Chicha 1 site]. In: Derevyanko AP, Molodin VI, editors. Problemy arkheologii, etnografii, antropologii Sibiri $i$ sopredel'nykh territorii. Tom 8. Novosibirsk: IAET SO RAN Publishing. p 386-95. In Russian.

Molodin VI, Parzinger G, Garkusha YN, Schneeweiss J, Grishin AE, Novikova OI, Chemyakina MA, Efremova NS, Marchenko ZV, Ovcharenko AP, Rybina EV, Mylnikova LN, Vasilev SK, Beneke N, Manshtein AK, Dyadkov PG, Kulik NA. 2004. Chicha-gorodishche perekhodnogo ot bronzy $k$ zelezu vremeni $v$ Barabinskoi lesostepi. Pervye resultaty issledovanii. [Chicha - fortified settlement of Transition period from Bronze Age to Iron Age in Baraba forest-steppe. First results]. Materialy po arkheologii Sibiri. Tom 2. Vypusk 4. Novosibirsk: IAET SO RAB Publishing. 336 p. In Russian.

Molodin VI, Parzinger G, Grishin AE, Marchenko ZV, Schneeweiss J. 2003. Prostranstvennovremennaya dinamika gorodishcha Chicha 1: analiz stratigraphii i planigraphii [Spatialtemporal dynamics of fortified settlement Chicha 1: stratigraphy and planigraphy analyzes]. In: Kiryushin YF, Tishkin AA, editors. Istoricheskii opyt khhozyaistvennogo $i$ kulturnogo osvoeniya Zapadnoi Sibiri. Book 1. Barnaul: Altai State University Publishing. p 316-22. In Russian.

Molodin VI, Parzinger H, Schneeweiß J, Garkuša JN, Grišin AE., Novikova OI, Efremova NS, Marčenko ŽV, Chemiakina MA, Myl'nikova LN, Becker H, Faßbinder J. 2002b. Čiča eine befestigte Ansiedlung der Übergangsperiode von der Spätbronze- zur Früheisenzeit in der Barabinsker Waldsteppe. Vorbericht der Kampagnen 1999-2001. Eurasia Antiqua 8:185-236.

Mook WG, Streurman HJ. 1983. Physical and chemical aspects of radiocarbon dating. Journal of the European study group on physical, chemical and mathematical techniques Applied to Archaeology. PACT 8:31-55.

Multidisciplinary investigations of the Bronze Age settlements in the Southern Trans-Urals (Russia). 2013. Krause R, Koryakova LN, editors. Frankfurter Archäologische Schriften 23. Bonn: Verlag Dr. Rudolf Habelt GmbH. 354 p.

Parzinger H. 2004. Die Skythen. München: Verlag C. H. Beck. 128 p.

Parzinger H. 2006. Die frühen Völker Eurasiens. Vom Neolithikum bis zum Mittelalter. München: Verlag C. H. Beck. 1046 p.

Pilipenko AS, Romaschenko AG, Molodin VI, Kulikov IV, Kobzev VE, Pozdnyakov DV, Novikova OI. 2008. Infant burials in dwellings at Chicha I in the Baraba forest-steppe: results of DNA analysis. Archaeology, Ethnology and Anthropology of Eurasia 2(34):57-67.

Potemkina TM. 1985. Bronzovyi vek lesostepnogo Pritobolya [Bronze Age of the Tobol River forest-steppe]. Moscow: Nauka Pablishing. 376 p. In Russian.

Reimer PJ, Baillie MGL, Bard E, Bayliss A, Beck JW, Bertrand CJH, Blackwell PG, Buck CE, Burr GS, Cutler KB, Damon PE, Edwards RL, Fairbanks RG, Friedrich M, Guilderson TP, Hogg AG, Hughen KA, Kromer B, McCormac G, Manning S, Bronk Ramsey C, Reimer RW, Remmele S, Southon JR, Stuiver M, Talamo S, Taylor FW, van der Plicht J, 
Weyhenmeyer CE. 2004. IntCal04 terrestrial radiocarbon age calibration, 0-26 cal kyr BP. Radiocarbon 46(3):1029-58.

Reimer P, Bard E, Bayliss A, Beck JW, Blackwell PG, Bronk Ramsey Ch, Buck CE, Cheng H, Edwards RL, Friedrich M, Grootes PM, Guilderson TP, Haflidason H, Hajdas I, Hatté Ch., Heaton TJ, Hoffmann DL, Hogg AG, Hughen KA, Kaiser KF, Kromer B, McCormac FG, Manning SW, Niu M, Reimer RW, Richards DA, Scott EM, Southon JR, Staff RA, Turney CSM, van der Plicht J. 2013. IntCal13 and Marine13 Radiocarbon Age Calibration Curves 050,000 Years cal BP. Radiocarbon 55(4):1869-87.

Riede F, Edinborough L. 2012. Bayesian radiocarbon models for the cultural transition during the Allerød in southern Scandinavia. Journal of Archaeological Science 39:744-56.

Samashev ZS, Bokovenko NA. 1983. Issledovaniya v Semipalatiskoi oblasti [Studies in Semipalatinsk Region]. In: Shilov VP, editor. Arkheologicheskie otkrytiya 1983 goda. Nauka Publishing. p 515-6. In Russian.

Schneeweiß J. 2007. Die Siedlung Čiča in der westsibirischen Waldsteppe I. Untersuchungen zur Keramik, Chronologie und kulturellen Stellung in der Spätbronzezeit und der Übergangsperiode zur frühen Eisenzeit. Archäologie in Eurasien 22. Mainz: Philipp von Zabern Verlag. 498 p.

Schneeweiß J. 2010. Protourbane" Siedlungen an der Wende vom 2. zum 1. Jahrtausend v. Chr. in der westsibirischen Waldsteppenzone. In: Horejs B, Kienlin TL, editors. Siedlung und Handwerk. Studien zu sozialen Kontexten in der Bronzezeit. Beiträge zu den Sitzungen der AG Bronzezeit 2007 und 2008. Universitätsforschungen zur Prähistorischen Archäologie 194. Bonn: Verlag Dr. Rudolf Habelt Bonn. p 157-71.

Schneeweiß J, Rjabogina N. 2014. Die Wechselwirkungen zwischen naturräumlichen Veränderungen und Kulturentwicklung in der westsibirischen Waldsteppenzone im 2. und 1. Jahrtausend v. Chr. In: Heinrich-Tamáska O, Hardt M, Révész L, Schenk W editors. Offene Landschaften. Siedlungsforschung. Archäologie - Geschichte - Geographie 31:63-93.

Scott M. 2000. Bayesian Methods: What can we gain at what cost? Radiocarbon 42(2):181.

Steier P, Rom W. 2000. The use of Bayesian statistics for 14C dates of chronologically ordered samples: A critical analysis. Radiocarbon 42(2):183-98.

Steier P, Rom W, Puchegger S. 2001. New methods and critical aspects in Bayesian mathematics for ${ }^{14} \mathrm{C}$ calibration. Radiocarbon 43(2A):373-80.

Stuiver M, Pollach HA. 1977. Discussion: reporting of ${ }^{14} \mathrm{C}$ data. Radiocarbon 19:355-63.

Stuiver M, Reimer PJ, Bard E, Beck JW, Burr GS, Hughen KA, Kromer B, McCormac FG, van der Plicht J, Spurk M. 1998. INTCAL98 radiocarbon age calibration, 24,000-0 cal BP. Radiocarbon 40(3):1041-83.

Svyatko SV, Mallory JP, Murphy EM, Polyakov AV, Reimer PJ, Schulting RJ. 2009. New radiocarbon dates and a review of the chronology of prehistoric populations from the Minusinsk basin, Southern Siberia, Russia. Radiocarbon 51(1):243-73.

Telford RJ, Heegaard E, Birks HJB. 2004. All age-depth models are wrong: but how badly? Quaternary Science Reviews 23 (1-2):1-5.

Troitskaya TN. 1985. Zavyalovskaya kultura i ee mesto sredi lesostepnykh kultur Zapadnoi Sibiri [Zavyalovo Culture and its place among Western Siberia forest-steppe cultures]. In: Vasilevskii RS, editor. Zapadnaya Sibir v drevnosti i srednevekove. Tyumen: Tyumen State University Publishing. p 54-69. In Russian. 
van der Plicht J. 1993. The Groningen Radiocarbon Calibration Program. Radiocarbon 35(1): 231-7.

Wardle K, Higham T, Kromer B. 2014. Dating the end of the Greek Bronze Age: a robust radiocarbon-based chronology from Assiros Toumba. PloS ONE 9/9.

Weninger F. 2011. Bayesian sequencing of radiocarbon dates. Diss. Univ. Wien. Unpublished $\mathrm{PhD}$ Thesis.

Weninger F, Steier P, Kutschera W, Wild EM. 2010. Robust Bayesian analysis, an attempt to improve Bayesian sequencing. Radiocarbon 52(3):962-83.

Wiener MH. 2014. Radiocarbon dating of the Theran eruption. Open Journal of Archaeometry 2.

Zakh VA. 2012. Periody transformatsii v istorii drevnikh obshchestv Tobolo-Ishimya v golotsene [Transformation periods in ancient society history of Tobol-Ishim area in Holocene]. Vestnik arkhaeologii, antropologii i etnografii 4(19):17-26. In Russian.

Zakh VA, Zimina OY, Ryabogina NE. 2011. Radiouglerodnye daty arkheologicheskikh i prirodnykh kompleksov Tobolo-Ishimya (po materialam Tobbolo-Ishimskoi ekspeditsii IPOS SO RAN) [Radiocarbon dates from archaeological and natural complexes of Tobol-Ishim area (on the materials of Tobol-Ishim expedition IPDN SB RAS)]. Vestnik arkhaeologii, antropologii i etnografii 1(18):219-33. In Russian. 


\begin{tabular}{|c|c|c|c|c|c|}
\hline Lab. ID & $\begin{array}{l}\text { 14C age } \\
\text { (BP) }\end{array}$ & Sample context & Material & $\begin{array}{l}\text { Calibrated date } \\
\text { range }( \pm 2 \sigma)\end{array}$ & $\delta 13 C$ \\
\hline Hd-24527 & $3792 \pm 23$ & moat E, layer 10 & soil & 2292-2142 BC & -25.9 \\
\hline$B \ln -5480$ & $3128 \pm 32$ & moat $\mathrm{E}$, layer 7 & horse $($ Equus)** & 1495-1296 BC & -20.9 \\
\hline KIA-18873 & $3128 \pm 28$ & moat $\mathrm{B}$, layer 7 & elk $(\text { Alces })^{* *}$ & 1493-1301 BC & - \\
\hline KIA-12439b & $3106 \pm 26$ & burial 1(1) & food crust & $1432-1295$ BC & -28.1 \\
\hline Bln-5483 & $3087 \pm 30$ & moat A, layer 38 & animal bone ${ }^{* *}$ & 1424-1271 BC & -21.4 \\
\hline KIA-16427 & $3086 \pm 27$ & moat A, layer $29 / 66$ & food crust & $1421-1276 \mathrm{BC}$ & -30.2 \\
\hline Bln-5533 & $3082 \pm 32$ & burial 3 & human** & 1424-1263 BC & -20.8 \\
\hline KIA-12439a & $3080 \pm 28$ & burial $1(2)$ & fish** & 1416-1266 BC & -18.7 \\
\hline Bln-5484a & $3071 \pm 36$ & moat $\mathrm{A}$, layer $42 \mathrm{~b}$ & elk (Alces)** & $1420-1231 \mathrm{BC}$ & -21.3 \\
\hline KIA-12438 & $3048 \pm 39$ & moat E, layer 11 & fish** & 1416-1208 BC & -25.1 \\
\hline KIA-12434 & $3045 \pm 38$ & house 7 , burned layer & charcoal & 1414-1208 BC & -24.6 \\
\hline KIA-16426 & $3045 \pm 28$ & house $3 b$ & food crust & 1396-1222 BC & -29.0 \\
\hline Bln-5536 & $3032 \pm 30$ & burial 6 & human** & 1398-1207 BC & -20.1 \\
\hline$B \ln -5486$ & $3027 \pm 28$ & moat A, layer 24 & elk $(\text { Alces })^{* *}$ & 1393-1135 BC & -22.3 \\
\hline Bln-5532 & $3018 \pm 33$ & burial 1(3) & human** & $1392-1129 \mathrm{BC}$ & -21.5 \\
\hline Bln-5534 & $2999 \pm 34$ & burial 4 & human** & 1382-1121 BC & -21.5 \\
\hline$B \ln -5535$ & $2996 \pm 32$ & burial 5 & human** & 1378-1121 BC & -21.3 \\
\hline Bln-5614 & $2959 \pm 32$ & house 20 , pit $445 a$ & charcoal & $1262-1056 \mathrm{BC}$ & -27.3 \\
\hline Bln-5485a & $2959 \pm 34$ & moat $A$, burned layer 6 & horse $(\text { Equus })^{* *}$ & 1269-1051 BC & -21.6 \\
\hline Bln-5294 & $2933 \pm 28$ & pit 155 & Charcoal & $1222-1038 \mathrm{BC}$ & -27.0 \\
\hline Hd-24518 & $2929 \pm 31$ & moat $\mathrm{E}$, layer 8 & Soil & $1219-1022 \mathrm{BC}$ & -25.7 \\
\hline$B \ln -5479$ & $2891 \pm 34$ & house 12 , layer $3 b$ & horse (Equus)** & 1208-977 BC & -21.8 \\
\hline$B \ln -5478$ & $2890 \pm 31$ & object 3 & horse $(E q u u s) * *$ & $1207-976 \mathrm{BC}$ & -21.6 \\
\hline KIA-12433 & $2878 \pm 26$ & pit 27 & charcoal & $1188-942 \mathrm{BC}$ & -25.4 \\
\hline KIA-16429 & $2839 \pm 27$ & house $3 \mathrm{a}$ & food crust & $1107-916 \mathrm{BC}$ & -26.1 \\
\hline Bln-5417 & $2838 \pm 32$ & house 3 & charcoal & $1109-914$ BC & -26.8 \\
\hline KIA-12436 & $2824 \pm 36$ & house 2 , pit 282 & charcoal & 1109-899 BC & -24.8 \\
\hline KIA-16428 & $2818 \pm 25$ & house $8 \mathrm{a}$, layer 3 & food crust & 1042-907 BC & -28.9 \\
\hline Bln-5412 & $2813 \pm 27$ & moat $A$, layer 10 , object 6 & charcoal & 1042-903 BC & -26.8 \\
\hline KIA-12435 & $2812 \pm 28$ & house 5 , pit 11 & charcoal & 1044-901 BC & -25.4 \\
\hline KIA-18871 & $2793 \pm 28$ & moat E2, layer 3e & animal bone $* *$ & 1013-848 BC & - \\
\hline KIA-16430 & $2773 \pm 30$ & house $8 a$, pit $34 b$ & food crust & $999-841 \mathrm{BC}$ & -27.1 \\
\hline Bln-5477 & $2736 \pm 27$ & house 10 , object 2 & horse (Equus)** & 930-817 BC & -20.9 \\
\hline$B \ln -5481$ & $2705 \pm 37$ & moat B, layer 4 & horse $(E q u u s)^{* *}$ & $918-803$ BC & -21.6 \\
\hline KIA-18874 & $2684 \pm 24$ & moat G & animal bone ${ }^{* *}$ & 896-804 BC & - \\
\hline KIA-12437 & $2680 \pm 36$ & moat E, layer 9 & charcoal & $901-800 \mathrm{BC}$ & -22.2 \\
\hline Bln-5297 & $2677 \pm 42$ & house 2 , object 5 & charcoal & $907-796 \mathrm{BC}$ & -25.0 \\
\hline Bln-5482 & $2665 \pm 34$ & object 5 & horse (Equus)** & 896-796 BC & -20.8 \\
\hline$B \ln -5298$ & $2643 \pm 30$ & house 2 , object 7 & charcoal & 894-787 BC & -25.2 \\
\hline Bln-5418 & $2623 \pm 54$ & house 8 , object 5 & animal bone $e^{* *}$ & $909-554 \mathrm{BC}$ & -20.0 \\
\hline$B \ln -5419$ & $2551 \pm 38$ & house $8 \mathrm{a}$, object 10 & animal bone ${ }^{* *}$ & $806-543$ BC & -20.0 \\
\hline KIA $12432 *$ & $2008 \pm 25$ & house 4 , layer 2 & charcoal & $83 \mathrm{BC}-59 \mathrm{AD}$ & - \\
\hline KIA $18872 *$ & $1984 \pm 23$ & house 6 , layer 2 & neat $(\mathrm{Bos}) * *$ & $41 \mathrm{BC}-66 \mathrm{AD}$ & - \\
\hline $\mathrm{B} \ln -5296^{*}$ & $1120 \pm 28$ & moat $\mathrm{C}$ & charcoal & 778-994 AD & - \\
\hline
\end{tabular}


Appendix 1

Radiocarbon ages, calibrated date range and carbon stable isotope values from Chicha site. The dates were calibrated in OxCal 4.2 (Bronk Ramsey 2009) using IntCal13 calibration curve (Reimer et al. 2013). (*samples belonging to the later Early Iron Age (phase 3 by Schneeweiß 2007) or Middle Ages, respectively. They are far beyond the focus of this paper and were not included in the analysis, ** collagen dated). 